OPEN ACCESS

Edited by:

Scott Andrew Whattam, King Fahd University of Petroleum and

Minerals, Saudi Arabia

Reviewed by:

Kent Condie,

New Mexico Institute of Mining and

Technology, United States

Elena Sizova

University of Graz, Austria

*Correspondence:

Anastassia Y. Borisova anastassia.borisova@get.omp.eu

Specialty section: This article was submitted to

Petrology,

a section of the journal

Frontiers in Earth Science

Received: 11 December 2020

Accepted: 26 January 2021

Published: 28 May 2021

Citation:

Borisova AY, Zagrtdenov NR, Toplis MJ, Bohrson WA, Nédélec A,

Safonov OG, Pokrovski GS, Ceuleneer G, Bindeman IN, Melnik OE,

Jochum KP, Stoll B, Weis U,

Bychkov AY, Gurenko AA, Shcheka S, Terehin A, Polukeev VM, Varlamov DA, Chariteiro K, Gouy S and de Parseval $P$ (2021) Hydrated Peridotite - Basaltic Melt Interaction Part I: Planetary Felsic

Crust Formation at Shallow Depth.

Front. Earth Sci. 9:640464.

doi: 10.3389/feart.2021.640464

\section{Hydrated Peridotite - Basaltic Melt Interaction Part l: Planetary Felsic Crust Formation at Shallow Depth}

Anastassia Y. Borisova ${ }^{1,2 *}$, Nail R. Zagrtdenov ${ }^{1}$, Michael J. Toplis ${ }^{3}$, Wendy A. Bohrson ${ }^{4}$ Anne Nédélec ${ }^{1}$, Oleg G. Safonov ${ }^{2,5,6}$, Gleb S. Pokrovski ${ }^{1}$, Georges Ceuleneer ${ }^{1}$, Ilya N. Bindeman ${ }^{7,8}$, Oleg E. Melnik ${ }^{9}$, Klaus Peter Jochum ${ }^{10}$, Brigitte Stoll ${ }^{10}$, Ulrike Weis ${ }^{10}$, Andrew Y. Bychkov ${ }^{2}$, Andrey A. Gurenko ${ }^{11}$, Suyatoslav Shcheka ${ }^{12}$, Artem Terehin ${ }^{5}$, Vladimir M. Polukeev ${ }^{5}$, Dmitry A. Varlamov ${ }^{5}$, Kouassi Chariteiro ${ }^{1}$, Sophie Gouy ${ }^{1}$ and Philippe de Parseval ${ }^{1}$

${ }^{1}$ Géosciences Environnement Toulouse, GET/OMP (CNRS, UT3, IRD, CNES), Toulouse, France, ${ }^{2}$ Geological Department, Lomonosov Moscow State University, Vorobievy Gory, Moscow, Russia, ${ }^{3}$ Institut de Recherche en Astrophysique et Planétologie (IRAP) UT3, CNRS, Toulouse, France, ${ }^{4}$ Department of Geology and Geological Engineering, Colorado School of Mines, Golden CO, United States, ${ }^{5}$ Korzhinskii Institute of Experimental Mineralogy, Chernogolovka, Moscow Region, Russia, ${ }^{6}$ Department of Geology, University of Johannesburg, Auckland Park, 2006, Johannesburg, South Africa, ${ }^{7}$ Department of Sciences, University of Oregon, Eugene, OR, United States, ${ }^{8}$ Fersman Mineralogical Museum, Leninsky Prospect 18, Moscow, Russia, 9 Institute of Mechanics, Moscow State University, 1- Michurinskii Prosp, Moscow, Russia, ${ }^{10}$ Climate Geochemistry Department, Max Planck Institute for Chemistry, Mainz, Germany, ${ }^{11}$ Centre de Recherches Pétrographiques et Géochimiques, UMR 7358, Université de Lorraine, 54501 Vandœeuvre-lès-Nancy, France, ${ }^{12}$ Bavarian Research Institute of Experimental Geochemistry and Geophysics (BGI), University of Bayreuth, Bayreuth, Germany

Current theories suggest that the first continental crust on Earth, and possibly on other terrestrial planets, may have been produced early in their history by direct melting of hydrated peridotite. However, the conditions, mechanisms and necessary ingredients for this crustal formation remain elusive. To fill this gap, we conducted time-series experiments to investigate the reaction of serpentinite with variable proportions (from 0 to $87 \mathrm{wt} \%$ ) of basaltic melt at temperatures of $1,250-1,300^{\circ} \mathrm{C}$ and pressures of $0.2-1.0 \mathrm{GPa}$ (corresponding to lithostatic depths of $\sim 5-30 \mathrm{~km}$ ). The experiments at $0.2 \mathrm{GPa}$ reveal the formation of forsterite-rich olivine (FO90-94) and chromite coexisting with silica-rich liquids $\left(57-71 \mathrm{wt} \% \mathrm{SiO}_{2}\right)$. These melts share geochemical similarities with tonalitetrondhjemite-granodiorite rocks (TTG) identified in modern terrestrial oceanic mantle settings. By contrast, liquids formed at pressures of $1.0 \mathrm{GPa}$ are poorer in silica $\left(\sim 50 \mathrm{wt} \% \mathrm{SiO}_{2}\right)$. Our results suggest a new mechanism for the formation of the embryonic continental crust via aqueous fluid-assisted partial melting of peridotite at relatively low pressures ( $0.2 \mathrm{GPa})$. We hypothesize that such a mechanism of felsic crust formation may have been widespread on the early Earth and, possibly on Mars as well, before the onset of modern plate tectonics and just after solidification of the first ultramaficmafic magma ocean and alteration of this primitive protocrust by seawater at depths of less than $10 \mathrm{~km}$.

Keywords: experiment, basaltic melt-serpentinite rock interaction, TTG, ophiolites, Hadean eon, Noachian, Mars, protocrust 


\section{INTRODUCTION}

The conditions and mechanisms that led to the production of the earliest intermediate to felsic (Si- and Al-enriched) crust on Earth and Mars are the subject of intense debate (Rudnick and Gao, 2003; Harrison, 2009; Reimink et al., 2014, 2016; Sautter et al., 2015, 2016; Burnham and Berry, 2017). There are some indications that this crust was composed of igneous rocks of granitic composition (I-type) and may have been formed in a tonalite-trondhjemite-granodiorite (TTG)-like environment, i.e., by partial melting of a garnet-bearing lower crust, as far back as the geological record goes (e.g., the parental melt of the 4.37-4.02 Ga Jack Hills detrital zircon crystals, Burnham and Berry, 2017). Ancient granodiorite rocks have also been identified on Mars (Sautter et al., 2015; Sautter et al., 2016), indicating that formation of felsic crust occurred on other terrestrial planets even without plate tectonics and subduction. In this context, melting of dry peridotite at shallow depths does not produce appropriate intermediate to felsic melt compositions comparable to that of bulk continental crust (Hirschmann et al., 1998; Rudnick and Gao, 2003; Harrison, 2009; Reimink et al., 2014, 2016; Burnham and Berry, 2017). As a result, most currently accepted models for the generation of felsic crust on the Earth or Mars consider a complex multi-stage process at different depths, which involves extraction of basaltic magma from peridotitic mantle followed by fractional crystallization (Reimink et al., 2014, 2016; Udry et al., 2018) and/or re-melting of hydrated mafic rocks at lithospheric conditions of $\geq 0.6 \mathrm{GPa}$ (Harrison, 2009; O’Neil and Carlson, 2017). However, specific conditions during the Hadean lead us to envisage petrological mechanisms that are not typical of present-day felsic magma generation (i.e., not involving subduction; see Herzberg et al., 2010; Sautter et al., 2016). For example, the early terrestrial crust of intermediate to felsic composition might have been created by direct melting of a serpentinized (e.g., hydrated) peridotite at shallow depths (Rudnick, 1995; Rudnick and Gao, 2003). A possible presentday analogue is the formation of tonalites-trondhjemites in the shallow mantle beneath oceanic spreading centers (called oceanic plagiogranites in this context) (Coleman and Peterman, 1975; Amri et al., 1996; Amri et al., 2007). Trondhjemite-tonalite veins are common features throughout the cores in the few sites of the Deep Sea Drilling Project, and Ocean Drilling, Integrated Ocean Drilling and International Ocean Discovery Programs (DSDP, ODP, and IODP) where the deep oceanic crust has been drilled along present-day spreading ridges. These rocks have been ascribed to local remelting processes in the presence of hydrothermal fluids along hightemperature normal shear zones. These rocks are not abundant (no more than $1 \%$ of the volume of the sections), but their abundance might be underestimated due to poor core recovery in the fault zones (e.g., Pietranik et al., 2017). Their origin is enigmatic, although understanding the origin of TTG rocks situated in modern oceanic lithosphere may open new perspectives on the formation of the first planetary felsic crust.

Rare low-pressure melting experiments $(\leq 1.0 \mathrm{GPa})$ involving peridotite and low water contents (up to $0.5 \mathrm{wt} \%$ in the bulk source) indicate that peridotite-derived partial melts may become enriched in $\mathrm{SiO}_{2}$ (up to $57 \mathrm{wt} \%$ ) and other lithophile elements (Al, alkalis), with abundances approaching those of continental crustal rocks (Hirschmann et al., 1998; Ulmer, 2001). The increase in the silica contents of partial melts at low pressures is generally considered to be due to the combined effects of water, alkalis, and low pressure on the structure of the aluminosilicate melt, shifting the olivine-pyroxene cotectics to higher $\mathrm{SiO}_{2}$ contents through a decrease in the silica activity coefficient (Kushiro, 1968; Hirschmann et al., 1998; Lundstrom, 2000).

As an alternative, or complement to direct hydrous melting of peridotite, a currently untreated question is to what extent the presence of basaltic melt may have an impact on the production of felsic crust. This impact may be direct (through chemical reactions with the host peridotite) or indirect (by providing a heat source). In this respect, experiments that reproduce basaltic melt-peridotite reaction at low pressures $(<0.8 \mathrm{GPa})$ are currently limited to systems undersaturated in aqueous fluid (e.g., Fisk, 1986; Kelemen et al., 1990; Morgan, and Liang, 2003; Van den Bleeken et al., 2010; 2011). Although the experiments show the presence of dry basaltic to andesitic-basaltic melts in association with olivine, no direct data exist concerning the partial melting of hydrated (serpentinized) peridotite (or serpentinite) triggered by the emplacement of basaltic melts at shallow crustal depths $(5-15 \mathrm{~km})$. This latter scenario is of primary interest in early Earth history (and possibly also for Mars), because the ultramafic-mafic protocrust formed from the crystallization of a magma ocean was most likely hydrated, either by volatiles released by the magma ocean itself or through interactions with liquid water available on the planetary surface (Albarède and Blichert-Toft, 2007; ElkinsTanton, 2012). A present-day analogue can be observed at the level of the mantle/petrologic Moho boundary in the oceanic lithosphere (at depths of $6 \mathrm{~km}$ ), where interactions of basaltic magmas with peridotites produce chromitite-dunite associations (Kelemen et al., 1995; Arai, 1997; Borisova et al., 2012; Zagrtdenov et al., 2018; Rospabé et al., 2019) and serpentinized peridotite (hydrated residual peridotite) undergoes partial melting (Benoit et al., 1999). Furthermore, such shallow conditions of serpentinite melting in the presence of basaltic melt might also occur in mantle plumes (Bindeman, 2008; Reimink et al., 2014, 2016; Borisova et al., 2020a), in Hadean heat-pipe volcanoes (Moore and Webb, 2013) or Hadean proto-rift volcanoes (Capitanio et al., 2020) and/or during meteorite impacts (Marchi et al., 2014).

The above considerations provide a strong motivation for the present study, which aims to directly investigate the generation of intermediate to felsic crust on young terrestrial planets. For this purpose, we have conducted a set of time-series experiments in serpentinite-basalt systems under relatively low pressures $(\leq 1 \mathrm{GPa}$ ), corresponding to depths of $\leq 30 \mathrm{~km}$. Modern (i.e., post-Archean) magmatism near the petrologic Moho in the oceanic lithosphere can then be used as a ground-truth test within its limits. 


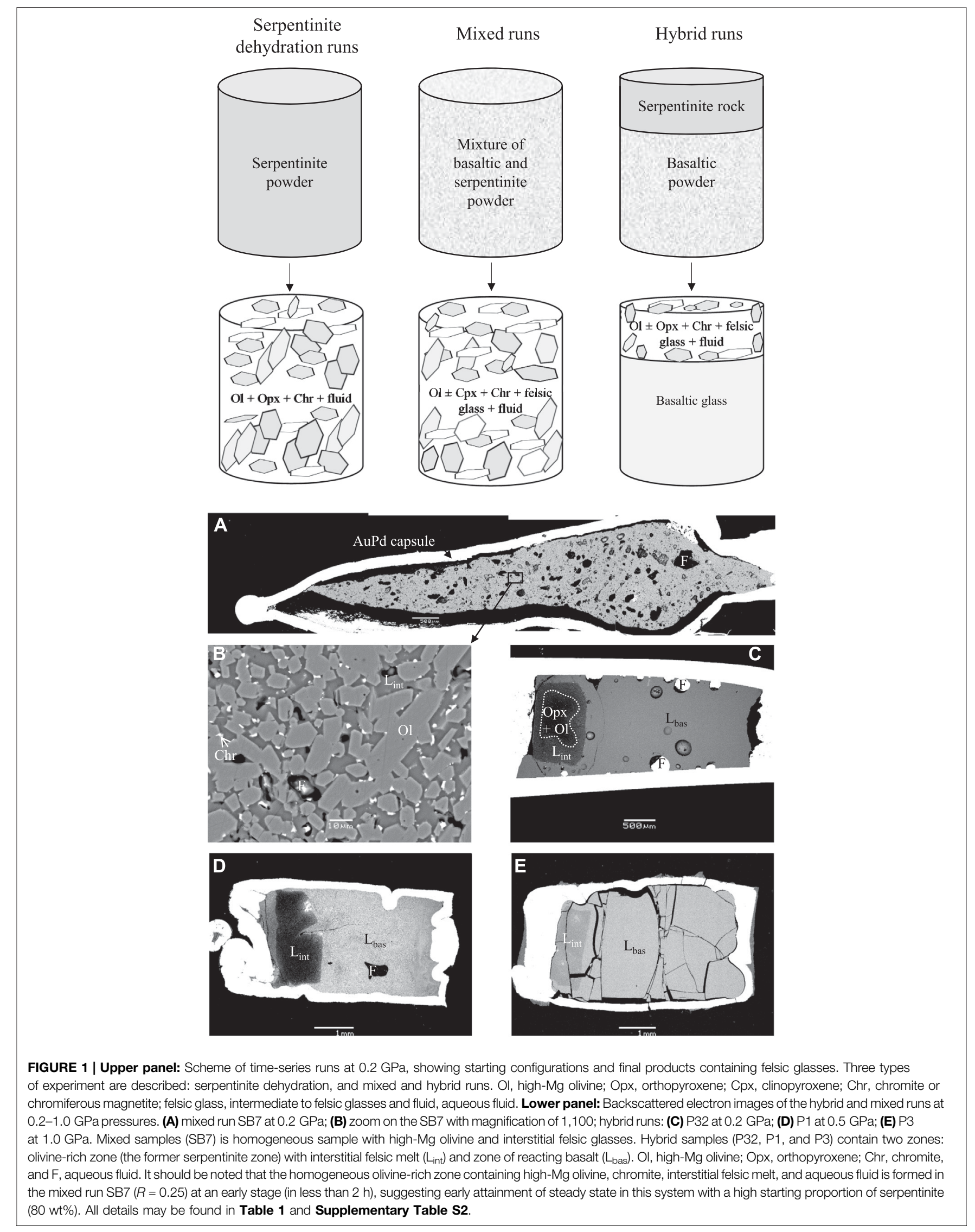




\section{EXPERIMENTAL STRATEGY AND METHODS}

\section{Experimental Strategy}

To investigate the serpentinite rock-basaltic melt reactions, we have conceived three types of time-series experiments: (i) pure serpentinite dehydration in a basalt-free system, and so-called (ii) "mixed" and iii) "hybrid" experiments in the serpentinite-basalt system as a function of pressure and basalt-to-serpentinite ratio. (Figures 1A-E; Table 1; Supplementary Tables S1, S2). The "mixed" experiments were performed on well-homogenized serpentinite and basaltic powders compressed together, whereas the "hybrid" experiments were performed using cylindrical pieces of serpentinite rock placed in the upper part of the capsule and a basaltic powder in the lower part of the capsule in contact with the base of the serpentinite cylinder (Figures 1A-E). These two distinct experimental setups were designed to simulate two principal geological scenarios of basaltic melt emplacement. The mixed experiments (with variable basaltto-serpentinite mass ratios, $\mathrm{R}_{\mathrm{bas} / \mathrm{serp}}$ or $\mathrm{R}$ from 0.25 to 4 ) simulate the case of efficient fertilization of peridotite in order to achieve a closer approach to equilibrium and obtain stable associations of the minerals and melts produced by the reactions on the relatively short time scales that are accessible experimentally. The hybrid experiments (with generally higher $\mathrm{R}$, from $\sim 3$ to $\sim 7$ ) were designed to simulate the process of basaltic melt infiltration into serpentinite rock, that does not necessarily reach equilibrium.

All experiments were conducted using two types of piston cylinder and an internally heated pressure vessel for durations ranging from $1 \mathrm{~min}$ to $120 \mathrm{~h}$ at pressures of $0.2,0.5$, and $1.0 \mathrm{GPa}$ and temperatures of 1,250 and $1,300^{\circ} \mathrm{C}$ (see Supplementary Materials for details). In modern oceanic settings, temperatures of $\sim 1,050^{\circ} \mathrm{C}$ are considered to be sufficient to initiate the reaction of serpentinized peridotite with basaltic magma at $0.2 \mathrm{GPa}$ (Borisova et al., 2012). In the present experimental study, however, we chose to use higher temperatures $\left(1,250-1,300^{\circ} \mathrm{C}\right)$ since these provide a closer analogue of the thermal conditions of the Hadean and early Martian upper mantle (Herzberg et al., 2010; Sautter et al., 2016). Redox conditions expressed relative to the conventional quartzfayalite-magnetite $f_{\mathrm{O} 2}$ buffer $\left[\Delta \mathrm{QFM}=\log _{10} f_{\mathrm{O} 2}\right.$ (experiment) $-\log _{10} f_{\mathrm{O} 2}(\mathrm{QFM})=+1.8$ to +4.6$]$ established in our experiments are comparable to those characteristic of the Jack Hills zircon crystals in equilibrium with the mantle (Trail et al., 2011). In addition, higher temperatures should substantially increase the rates of serpentinite-basaltic melt reactions. On the time scale of laboratory experiments, such conditions correspond to the complete melting of basalt, which is consistent with most existing models of basaltic melt extraction from the mantle and its emplacement in the upper crust (Fisk, 1986; Hirschmann et al., 1998; Ulmer, 2001; Morgan and Liang, 2003).

\section{Experimental Conditions and Starting Materials}

To describe mechanisms of the serpentinite dehydration and the serpentinite interaction with basaltic melt, the duration of the experiments varied from $1 \mathrm{~min}$ to $120 \mathrm{~h}$. The experiments were performed in two laboratories: Korzhinskii Institute of Experimental Mineralogy (Russia) and Bavarian Research Institute of Experimental Geochemistry and Geophysics (Germany) (Table 1; Supplementary Table S2). The dehydration runs and the mixed runs were performed for durations of $0.5,2,5$, and $48 \mathrm{~h}$. The starting basalt used in the hybrid and mixed experiments is an enriched mid-ocean ridge basaltic glass containing $8.2 \mathrm{wt} \% \mathrm{MgO}$ and $0.7 \mathrm{wt} \% \mathrm{H}_{2} \mathrm{O}$ (Supplementary Table S1) from the Knipovich ridge of the Mid Atlantic Ridge sampled by dredging during the 38th expedition of R/V Akademik Mstislav Keldysh (number 3786/ 3, Sushchevskaya et al., 2000). The serpentinite (11.9 wt\% $\mathrm{H}_{2} \mathrm{O}$ ) (Supplementary Table S1) used as a starting material is from a homogeneous antigorite-dominated sample from Zildat, in the Ladakh area, northwest Himalayas (TSL-19) (Deschamps et al., 2010). This sample has accessory magnetite but no trace of chromite, olivine or orthopyroxene. The serpentinite was prepared either as doubly polished $\sim 1 \mathrm{~mm}$ high and $\sim 2.6 \mathrm{~mm}$ diameter cylinders (for hybrid runs) or as serpentinite powder ( $<100 \mu \mathrm{m}$; for mixed runs).

The use of $\mathrm{Au}_{80} \mathrm{Pd}_{20}$ alloy for the experimental capsule material avoids $\mathrm{Fe}$ diffusion into the capsule because of the negligibly small iron solubility at the temperature-pressureredox conditions of our experiments (Balta et al., 2011). Therefore, the capsules were not pre-doped with $\mathrm{Fe}$. The redox conditions in our experiments were buffered by the initial $\mathrm{Fe}^{2+} / \mathrm{Fe}^{3+}$ ratios imposed by the starting basaltic glass and serpentinite in the capsule. Note that our run durations $(\leq 48 \mathrm{~h})$ are too short to allow use of a double-capsule technique with common mineral buffers of oxygen fugacity that require longer times to attain equilibrium (Matjuschkin et al., 2015). The redox conditions (i.e., oxygen fugacity, $f_{\mathrm{O} 2}$ ) during the runs are estimated from the compositions of co-existing olivine and chromite using equations of Ballhaus et al. (1991) that yield $\triangle \mathrm{QFM}$ values of +1.8 to +4.6 (where $\triangle \mathrm{QFM}$ denotes the $\log f_{\mathrm{O} 2}$ value relative to the quartz-fayalite-magnetite buffer, Supplementary Table S2). Additionally, the $\mathrm{Fe}^{2+} / \mathrm{Fe}^{3+}$ ratios in several glass run products were derived from XANES (Xray absorption near edge structure) spectroscopy using the $\mathrm{Fe}$ K-edge at the European Synchrotron Radiation Facility (ESRF) in Grenoble, France (Supplementary Figure S1). The $\mathrm{Fe}^{2+} / \mathrm{Fe}^{3+}$ ratios obtained by XANES correspond to $\triangle \mathrm{QFM}(+1.8$ to +3.6$)$ based on model of Borisov et al. (2018) (Supplementary Table S2), in excellent agreement with the values estimated from phase composition. The relatively oxidized conditions inferred for our runs are principally the result of the presence of water, although partial $\mathrm{H}_{2}$ loss through the capsule wall cannot be fully excluded. However, redox potential does not have a significant influence on the concentrations of the major redox-insensitive elements of the felsic crust (predominantly $\mathrm{Si}$, and $\mathrm{Al}$ ).

We used the law of mass conservation and the minimization code of Oliphant (2006) (version 1.17). Two steps were applied to calculate phase proportions obtained in hybrid runs. In the first step, the initial MORB glass composition was introduced for the compositions of $\mathrm{L}_{\text {bas }}$ (basaltic liquid) and $\mathrm{L}_{\text {int }}$ (interstitial felsic liquid) (Supplementary Tables S1, S2). In the second step, the 
basaltic and interstitial glasses $\left(\mathrm{L}_{\text {bas }}\right.$ and $\mathrm{L}_{\text {int }}$, respectively) were distinguished as different phases. The run products (glasses and minerals) were analyzed for chemical compositions (Supplementary Tables S3, S4; Supplementary Material) to make reasonable comparison with natural felsic melts and magmas. Furthermore, thermodynamic modelling was performed to constrain the equilibrium compositions of the liquids, minerals as well as fluid produced during serpentinite dehydration and responsible for the felsic melt production (Supplementary Tables S5-S7; Supplementary Material).

\section{Analytical and Microanalytical Methods}

The bulk-rock chemical compositions of the starting serpentinite and basalt samples have been analyzed by inductively coupled plasma-mass spectrometry (ICP-MS) and inductively coupled plasma-optical emission spectroscopy (ICP-OES), using a method developed at the SARM (Nancy, France). Scanning electron microscope (SEM) and electron probe microanalysis and mapping (EPMA) of minerals and glasses were performed at the Géosciences Environnement Toulouse (GET, Toulouse, France) laboratory and at the Centre de Microcaractérisation Raimond Castaing (Toulouse, France). Secondary ion mass spectrometry (SIMS) was applied to measure the $\mathrm{H}_{2} \mathrm{O}$ contents at CRPG-CNRS (Nancy, France). Laser ablation-inductively coupled plasma-mass spectrometry (LA-ICP-MS) was applied to analyze major and trace element contents at the Max Planck Institute for Chemistry, (Mainz, Germany). XANES spectroscopy was used to estimate iron redox state in selected experimental glass products from $\mathrm{Fe} \mathrm{K}$-edge XANES spectra acquired at the FAME beamline of the European Synchrotron Radiation Facility (ESRF, France). All details of the applied methods may be found in the Supplementary Material.

\section{Modelling Approaches}

To interpret the experimental and analytical data obtained in this study and to enable comparisons with natural systems, we employed complementary modelling approach. Note that there is no currently available thermodynamic model and associated software tools allowing to directly simulate the aqueous fluidassisted melting of serpentinite in the presence of basaltic melt at pressures below $1 \mathrm{GPa}$, that could predict, simultaneously and within the same thermodynamic framework, the compositions of fluid, melts and minerals. By contrast, robust thermodynamic models currently exist for i) hydrous melts and ii) aqueous fluid phase. Therefore, we conducted two types of thermodynamic modelling to better constrain the compositions of the different phases produced in the experiments: i) calculations of liquid and mineral phase proportions and compositions formed at different physical chemical conditions (temperature, pressure, T-P) using MELTS and Magma Chamber Simulator, MCS software and ii) calculations of the equilibrium aqueous fluid composition and major element speciation in the fluid phase to constrain the capacity of the aqueous phase to mobilize and fractionate major elements at the experimental T-P conditions from the initial materials (basalt and serpentinite). All details of the modelling part are reported in Supplementary Material and Supplementary Tables S5-S7.

\section{RESULTS}

\section{Experimental Sample Description}

In this section, we describe the results of 23 experimental runs performed at $0.2-1.0 \mathrm{GPa}$ and $1,250-1,300^{\circ} \mathrm{C}$ to investigate pure serpentinite dehydration and serpentinite-basalt interaction in the mixed and hybrid systems with different durations $(1 \mathrm{~min}-120 \mathrm{~h})$, different proportions of serpentinite (13-100 wt\%) and variable basalt-to-serpentinite initial ratios $(R=0.25-6.5)$ in the starting material (Table 1; Supplementary Table S2).

\section{Dehydration Experiments at $0.2-0.5 \mathrm{GPa}$}

Three experiments on pure serpentinite dehydration (100 wt\% serpentinite) at $0.2-0.5 \mathrm{GPa}$ and $1,250^{\circ} \mathrm{C}$ were performed with different run durations. In experiment P29 (0.5 h duration), we observe a very porous aggregate consisting of enstatite $\left[92-95 \mathrm{Mg} \#=100 \mathrm{Mg} /\left(\mathrm{Mg}+\mathrm{Fe}^{2+}\right)\right]$, high-Mg olivine $\left(\mathrm{Fo}_{91-92}\right.$, mol\% forsterite) and chromite [69-73 Mg\#, and 68-95 Cr\# = 100 $\mathrm{Cr} /(\mathrm{Cr}+\mathrm{Al})$, Figures 1, 2, Supplementary Tables S2, S3]. Similarly, in the long-duration experiments P27 and P28 $(48 \mathrm{~h})$, the products are represented by a re-crystallized powder containing enstatite, high-Mg olivine and chromite. No trace of silicate glass was found in the run products. In all dehydration experiments at 0.2 and $0.5 \mathrm{GPa}$, fluid was present, likely produced by serpentinite decomposition.

\section{Mixed Experiments at $0.2 \mathrm{GPa}$}

Based on textural and compositional characteristics, three types of mineral-glass assemblage can be distinguished in nine samples from the mixed experiments on serpentinite-basaltic melt reactions with different proportions of serpentinite $(R=$ $0.25-4.0$ ) in the starting material.

1) Most samples of the $S B$ (Serpentinite-Basalt) series with high initial proportions of serpentinite $(R=0.25-1.0)$ are characterized by a homogeneous zone of polyhedral unzoned crystals of high-Mg olivine ( $\left.\mathrm{Fo}_{90-94} \mathrm{~mol} \%\right)$ associated with interstitial felsic glasses $\left(\mathrm{SiO}_{2}=\right.$ 62-71 wt\%) as well as fluid bubbles (Figures 1A,B, 2). Chromite $(\mathrm{Cr} \#=68-89 ; \mathrm{Mg} \# 56-73)$ is associated with the euhedral olivine grains, and crystals of clinopyroxene (Mg\# 58-68) are characteristic of the runs with $R=1$. Figures 1A,B, 2 show that samples SB7, SBbis2, SBter3 with high initial proportions of serpentinite $(R=0.25)$ are characterized by a single zone composed of polyhedral unzoned olivine $\left(\mathrm{FO}_{90-94}\right)$ and chromite crystals associated with interstitial felsic glasses $\left(\mathrm{L}_{\mathrm{int}}\right)$ and interstitial crystals of chromite and fluid bubbles. Remarkably, the proportions of interstitial melt are high (33-40 wt\%).

2) Experiments SB1, SB4, SBbis1, and SBter2, with lower initial proportions of serpentinite $(R=1-4)$, are characterized by polyhedral unzoned olivine 
TABLE 1 | Experimental run conditions and the resulting phases with the phase proportions.

\begin{tabular}{|c|c|c|c|c|c|c|c|c|}
\hline \multirow[t]{2}{*}{ № } & \multirow[t]{2}{*}{ Run } & \multirow{2}{*}{$\begin{array}{c}P \\
\text { (GPa) }\end{array}$} & \multirow{2}{*}{$\begin{array}{c}\mathrm{T} \\
\left.{ }^{\circ} \mathrm{C}\right)\end{array}$} & \multirow{2}{*}{$\begin{array}{l}\text { Time } \\
\text { (h) }\end{array}$} & \multicolumn{2}{|c|}{$\begin{array}{l}\text { Percentage of } \\
\text { the starting } \\
\text { components } \\
\text { (wt\%) }\end{array}$} & \multirow{2}{*}{$\begin{array}{c}\text { R } \\
\\
\text { BAS-to-SERP } \\
\text { mass } \\
\text { ratio }\end{array}$} & \multirow{2}{*}{$\begin{array}{c}\text { Resulting experimental phases } \\
\text { (Phase proportion in wt\%) }\end{array}$} \\
\hline & & & & & SERP & BAS* $^{*}$ & & \\
\hline \multicolumn{9}{|c|}{ Serpentinite dehydration experiments } \\
\hline 1 & P29 & 0.2 & 1250 & 0.5 & 100 & - & 0 & OI (54.1) + Opx (30.4) + Chr (2.6) + F(12.8) \\
\hline 2 & P28 & 0.2 & 1250 & 48 & 100 & - & 0 & $\mathrm{Ol}+\mathrm{Opx}+\mathrm{Chr}+\mathrm{F}$ \\
\hline 3 & P27 & 0.5 & 1250 & 48 & 100 & - & 0 & Ol (55.8) + Opx (28.6) + Chr (2.7) + F(12.8) \\
\hline \multicolumn{9}{|c|}{ Mixed experiments } \\
\hline 4 & SB1 & 0.2 & 1250 & 2 & 19.95 & 80.05 & 4.0 & OI (39.6) + Cpx (22.3) + Chr (6.8) + Lint $(34.0)+F(3.3)$ \\
\hline 5 & SB4 & 0.2 & 1250 & 2 & 49.89 & 50.11 & 1.0 & $\mathrm{Ol}+\mathrm{Cpx}+\mathrm{Chr}+\mathrm{L}_{\mathrm{int}}+\mathrm{F}$ \\
\hline 6 & SB7 & 0.2 & 1250 & 2 & 80.01 & 19.99 & 0.25 & Ol (59.2) + Chr (6.5) + Lint $(33.5)+F(5.9)$ \\
\hline 7 & SBbis3 & 0.2 & 1250 & 5 & 19.95 & 80.05 & 4.0 & $\mathrm{Ol}+\mathrm{L}$ bas $+\mathrm{F}$ \\
\hline 8 & SBbis1 & 0.2 & 1250 & 5 & 49.89 & 50.11 & 1.0 & Ol (37.9) + Cpx (19.3) + Chr (6.7) + Lint $(39.9)+F(2.1)$ \\
\hline 9 & SBbis2 & 0.2 & 1250 & 5 & 80.01 & 19.99 & 0.25 & Ol (59.4) + Chr (6.0) + L int $(33.4)+F(6.1)$ \\
\hline 10 & SBter1 & 0.2 & 1250 & 48 & 19.95 & 80.05 & 4.0 & $L$ bas $+F$ \\
\hline 11 & SBter2 & 0.2 & 1250 & 48 & 49.89 & 50.11 & 1.0 & Ol (36.0) + Cpx (22.0) + Chr (7.1) + Lint $(38.9)+F(2.1)$ \\
\hline 12 & SBter3 & 0.2 & 1250 & 48 & 80.01 & 19.99 & 0.25 & $\mathrm{Ol}(57.5)+\mathrm{Chr}(6.0)+\mathrm{L}_{\text {int }}(35.0)+\mathrm{F}(6.5)$ \\
\hline \multicolumn{9}{|c|}{ Hybrid experiments } \\
\hline 13 & P37 & 0.2 & 1250 & 0.5 & 28.2 & 71.8 & 2.5 & $L$ bas $(72.8)+L \operatorname{int}(0.4)+\mathrm{Ol}(17.0)+\mathrm{Opx}(6.8)+\mathrm{Cpx}+$ ChrMgt $(0.0)+F(3.0)$ \\
\hline 14 & P32 & 0.2 & 1250 & 2.5 & 17.7 & 82.3 & 4.6 & $\mathrm{~L}$ bas $(72.7)+\mathrm{L} \operatorname{int}(8.7)+\mathrm{OI}(10)+\mathrm{Opx}(7)+\mathrm{Chr}(0.0)+\mathrm{F}(1.6)$ \\
\hline 15 & P35 & 0.2 & 1250 & 5 & 18.8 & 81.2 & 4.3 & $L$ bas $+L$ int $+O I+O p x+C h r+C h r M g t+A m p h+F$ \\
\hline 16 & P33 & 0.2 & 1250 & 48 & 19.8 & 80.2 & 4.1 & $L$ bas $(57.1)+L \operatorname{int}(15.4)+\mathrm{Ol}(13.1)+\mathrm{Opx}^{*}(0.0)+\mathrm{Chr}(6.0)+$ Amph (6.6) $+\mathrm{F}(1.7)$ \\
\hline 17 & P42 & 0.2 & 1250 & 120 & 17.6 & 82.4 & 4.7 & $L$ bas $(\sim 58)+L \operatorname{int}(\sim 27.8)+\mathrm{Ol}(12.8)+$ ChrMgt $(0.0)+F(1.4)$ \\
\hline 18 & P1 & 0.5 & 1300 & 0.02 & 19.2 & 80.8 & 4.2 & $\mathrm{~L}$ bas $+\mathrm{L}$ int $+\mathrm{Ol}+\mathrm{Opx}+\mathrm{Chr}+\mathrm{F}$ \\
\hline 19 & P15 & 0.5 & 1300 & 0.5 & 15.7 & 84.3 & 5.4 & $L$ bas $+\mathrm{L}$ int $+\mathrm{Ol}+\mathrm{Opx}+$ ChrMgt \\
\hline 20 & P18 & 0.5 & 1300 & 5 & 13.4 & 86.6 & 6.5 & $\mathrm{~L}$ bas $+\mathrm{L}$ int $+\mathrm{Ol}+\mathrm{Opx}+\mathrm{Mgt}+\mathrm{Chr}$ \\
\hline 21 & P36 & 0.5 & 1250 & 8 & 14.6 & 85.4 & 5.8 & $L$ bas $(+F)$ \\
\hline 22 & P3 & 1.0 & 1300 & 2.5 & 15.3 & 84.7 & 5.5 & $L$ bas $+L$ int + Ol + Opx + ChrMgt \\
\hline 23 & P7 & 1.0 & 1300 & 9 & 15.9 & 84.1 & 5.3 & $\mathrm{~L}$ bas \\
\hline
\end{tabular}

${ }^{*} P$, pressure; T, temperature; SERP, serpentinite; BAS, basalt; L int, interstitial glass; L bas, hydrous basaltic glass; Serp, serpentine minerals; Ol, olivine; Opx, orthopyroxene; Opx*, ferrosilite; Cpx, diopside; Amph, amphibole; Chr, chromite; ChrMgt, chromiferous magnetite.

phenocrystals. The matrix of these samples contains a clinopyroxene-olivine assemblage with interstitial felsic glasses $\left(\mathrm{L}_{\text {int }}\right)$. Oxide minerals are represented by chromite phenocrysts.

3) Finally, the longest run sample SBter1 ( $48 \mathrm{~h})$ with the lowest initial proportion of serpentinite $(20 \mathrm{wt} \%)$ is represented by homogeneous basaltic glass formed by complete hybridization of the starting basaltic liquid with serpentinite. By contrast, the intermediateduration sample SBbis3 $(5 \mathrm{~h})$ is characterized by a residual olivine-rich zone, even though the starting material contains the same proportion of serpentinite as SBter1 (20 wt\%).

\section{Hybrid Experiments at $0.2 \mathrm{GPa}$}

The samples from hybrid experiments with low starting proportions of serpentinite $(18-28 \mathrm{wt} \%$; $\mathrm{R}=2.5-4.7)$ produced at $0.2 \mathrm{GPa}$ pressure show two distinct zones: a former serpentinite (or olivine-rich) zone and a zone of quenched basaltic melt (Figures 1C, 2; Table 1; Supplementary Tables S2, S3). The olivine-rich zone in sample P37 shows a core composed of enstatite $(\mathrm{Mg} \#=96.5 \pm 2.1)$ and high $-\mathrm{Mg}$ olivine $\left(\mathrm{Fo}_{93 \pm 1}\right)$, and a periphery $(80-280 \mu \mathrm{m}$ thick) consisting of olivine and interstitial felsic glass. In sample P32, which was kept for $2.5 \mathrm{~h}$ at $1,250^{\circ} \mathrm{C}$ and $0.2 \mathrm{GPa}$, the former serpentinite zone has a harzburgitic core (olivine $\mathrm{Fo}_{89 \pm 1}$ and orthopyroxene $\mathrm{Mg \#}=95 \pm$ 3 ) and an outer thick rim composed of olivine and interstitial glass. Chromite is localized exclusively in the former serpentinite zone (Figures 1,2). In sample P35, which was produced after $5 \mathrm{~h}$ at $1,250{ }^{\circ} \mathrm{C}$ and $0.2 \mathrm{GPa}$, a large $(\sim 200 \times 290 \mu \mathrm{m})$ aggregate of chromite is observed in the former serpentinite zone at the contact with the hydrous basalt glass. Moving away from the contact to the center of the former-serpentinite zone, pockets of interstitial glass can be found with rare crystals of amphibole and zoned olivine (more magnesian in the core and more ferric at the rim). The abundance of interstitial glass is lower in the olivine-rich area consisting of olivine and enstatite (olivine $\mathrm{Fo}_{80 \pm 7}$ and orthopyroxene $\mathrm{Mg} \#=92 \pm 2$ ). For the experiment conducted for $48 \mathrm{~h}$ under these conditions (run P33), the olivine-rich zone comprises euhedral zoned olivine crystals with highly magnesian cores and more ferrous rims associated with interstitial felsic glasses and interstitial crystals of clinopyroxene, amphibole and fluid 

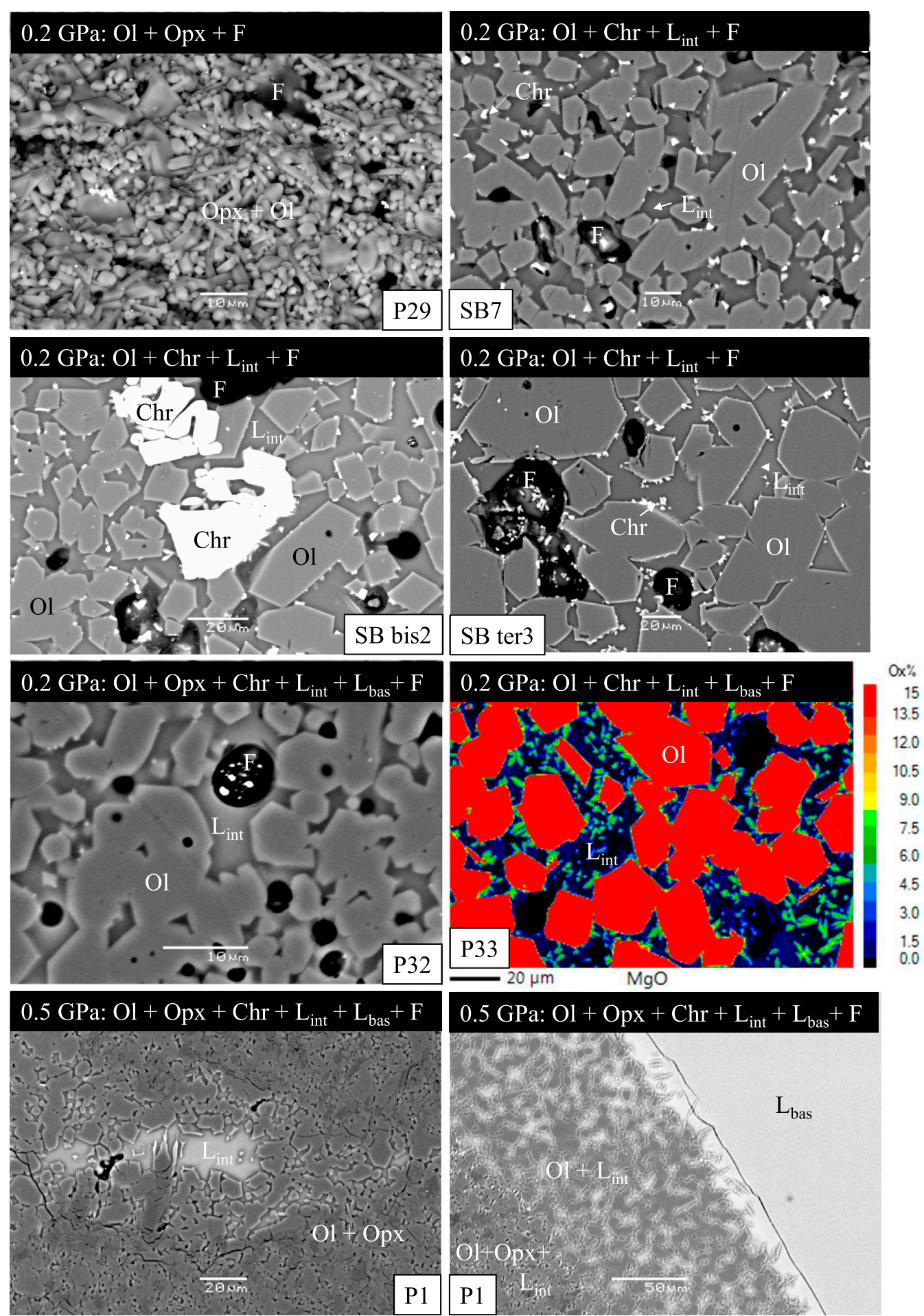

FIGURE 2 | Backscattered electron images and elemental X-ray maps of the hybrid and mixed runs to investigate aqueous fluid-assisted partial melting of peridotite at pressures of 0.2 and $0.5 \mathrm{GPa}$. The images show mineral, glass and fluid phase associations observed in the capsules, particularly the olivine-rich zones after quenching. Ol, Opx, Chr, Lint, L bas, and F on the images stand for olivine, orthopyroxene, chromite, interstitial and basaltic glass, and fluid bubbles, respectively. The run numbers correspond to those used in Table 1; Supplementary Table S2. (P29) The serpentinite dehydration sample produced at 0.2 GPa displays a single zone represented by enstatite with high-Mg olivine and orthopyroxene. (SB7, SB bis2, and SB ter3) The mixed samples with highest initial proportions of serpentinite (80 wt\%; $R=0.25$ ) are characterized by a unique polyhedral olivine-rich domain of unzoned crystals of olivine associated with interstitial felsic glass (Lint) and fluid bubbles. Chromite is associated with the euhedral olivine grains (high-Mg olivine Fogo-94). (P32) The hybrid run sample P32 lasting $2.5 \mathrm{~h}$ at $1,250^{\circ} \mathrm{C}$ and $0.2 \mathrm{GPa}(R=4.6)$ shows a former-serpentinite zone with an inner harzburgite part and an outer olivine-rich part (olivine $\mathrm{Fo}_{89+1}$ ) composed of olivine and interstitial glass. Chromite is localized 
FIGURE 2 | exclusively in the former-serpentinite zone. (P33) The hybrid P33 run was performed at $0.2 \mathrm{GPa}$ and $1,250^{\circ} \mathrm{C}$ for $48 \mathrm{~h}(R=4.1)$. The olivine-rich zone comprises euhedral zoned crystals of olivine associated with interstitial felsic glasses and interstitial crystals of clinopyroxene, amphibole and fluid bubbles. Chromite and chromiferous magnetite are located in the interstitial zones between the euhedral olivine grains (olivine Fo90 \pm 4 ) and are also associated with amphibole microcrystals grown around the Cr-rich spinels. (P1) A quenched glass zone and former-serpentinite zone are present in the hybrid sample P1 produced at 0.5 GPa pressure in the shortest duration experiment ( $1 \mathrm{~min}, R=4.2$ ). The former-serpentinite zone contains fine-grained (5-10 $\mu \mathrm{m})$ aggregates of olivine Fog5, enstatite, chromite, and interstitial glass of basaltic andesite composition. Chromite crystals (few microns in size) are disseminated within this zone. The bubbles in the quenched melt zone are evidence for the presence of water fluid during quenching. The textures demonstrate that the formation of the felsic liquids precedes the complete dissolution of orthopyroxene in the olivine-rich zones of the shortest-duration runs at 0.5 GPa. All data on the hybrid and mixed samples may be found in the Supplementary Tables S2, S3.

bubbles (Figure 2). Chromite and chromiferous magnetite are located in the interstitial zones between the euhedral olivine grains (high-Mg olivine $\mathrm{Fo}_{90 \pm 4}$ ) and are also associated with amphibole microcrystals grown around the Cr-rich spinels. Only one crystal of ferrous orthopyroxene (hypersthene) is recorded in association with interstitial glass. In sample P42 (120 h), which contains a quenched melt zone of hydrous basaltic glass with rare euhedral olivine, the olivine-rich zone consists of euhedral olivine crystals $\left(\mathrm{Fo}_{92.8 \pm 0.5}\right)$, chromiferous magnetite and interstitial glass of dacitic composition.

\section{Hybrid Experiments at $0.5 \mathrm{GPa}$}

The following group of samples with low initial proportions of serpentinite (13-19 wt\%; $R=4.2-6.5)$ in the starting material was produced at $0.5 \mathrm{GPa}$ and $1,300^{\circ} \mathrm{C}$ (except $\mathrm{P} 36$ at $1,250^{\circ} \mathrm{C}$ ) with run durations from $1 \mathrm{~min}$ to $8 \mathrm{~h}$ (Table 1; Supplementary Tables S2, S4). In sample P1 with the shortest run duration (1 min), the quenched glass zone and former-serpentinite zone are both present. The former-serpentinite zone contains fine-grained aggregates $(5-10 \mu \mathrm{m})$ of high-Mg olivine $\mathrm{Fo}_{95}$, enstatite with $\mathrm{Mg} \#=95$, chromite $(\mathrm{Cr} \#=89)$ and an interstitial glass of basaltic andesite composition (Figures 1D, 2). Chromite crystals (a few microns in size) are disseminated within this zone. The bubbles in the quenched melt zone are evidence for the presence of fluid water during quenching. Sample P15 (0.5 h) also shows two distinct zones (quenched basaltic melt zone and olivine-rich zone). The quenched basaltic melt zone consists of hydrous basaltic glass characterized by a high magnesium content (11 wt\% MgO). The former serpentinite zone consists of 5-20 $\mu \mathrm{m}$ aggregates of high-Mg olivine $\mathrm{Fo}_{93}$ and enstatite with $\mathrm{Mg \#}=97$. These aggregates are associated with an interstitial glass of andesitic composition and chromiferous magnetite. The outer part of this zone is characterized by a layer $(\sim 120 \mu \mathrm{m}$ thick), consisting of olivine crystals and interstitial glass. Chromiferous magnetite is concentrated in two large areas (up to $200 \mu \mathrm{m}$ and $400 \mu \mathrm{m}$ in size) or disseminated near these areas. Sample P18 (5 h of interaction) is also characterized by a hydrous basaltic zone and a former-serpentinite zone (Table 1; Supplementary Tables S2, S4). However, in this case, the olivine-rich zone consists of two areas; the outer area of nearly $200 \mu \mathrm{m}$ width contains olivine and basaltic interstitial glass with disseminated chromite (a few microns in size), while the inner area is situated $200 \mu \mathrm{m}$ from quenched basaltic glass. This inner area consists of high-Mg olivine $\mathrm{Fo}_{93}$, enstatite with $\mathrm{Mg} \#=97$ and contains aggregate of magnetite $(\sim 20 \times 40 \mu \mathrm{m})$. For the longest experiment of this series (P36, $8 \mathrm{~h})$, serpentinite has completely dissolved into the basalt melt (Table 1; Supplementary Tables S2, S4). Run products show a homogeneous basaltic glass with high $\mathrm{MgO}$ content (11.5 wt\%). More details are reported in Borisova et al. (2020a). Numerous bubbles with dendritic amphibole aggregates are present in the glass, suggesting amphibole growth upon quenching.

\section{Hybrid Experiments at $1.0 \mathrm{GPa}$}

Two experiments with low initial proportions of serpentinite $(\sim 15 \mathrm{wt} \% ; R=5.3-5.5)$ in the starting material were performed at $1.0 \mathrm{GPa}$ and $1,300^{\circ} \mathrm{C}$. The run products from experiment P3 $(2.5 \mathrm{~h})$ contain a basaltic glass zone and the formerserpentinite zone (Figure 1E; Table 1; Supplementary Tables S2, S4). High-Mg olivine $\left(\mathrm{Fo}_{92}\right)$, enstatite with $\mathrm{Mg} \#=96$ and chromiferous magnetite are associated with interstitial glass of basaltic composition (up to $51 \mathrm{wt} \% \mathrm{SiO}_{2}$ ) in the formerserpentinite zone. A longer-duration experiment (P7, 9h) yields products containing hydrous basaltic glass with $13.0 \mathrm{wt}$ $\% \mathrm{MgO}$ (Supplementary Tables S2, S4). More details are reported in Borisova et al. (2020a).

\section{Summary of the Major Findings From the Whole Series of Experimental Data}

1) Highly magnesian olivine ( $\mathrm{Fo}_{91-92}, \mathrm{~mol} \%$ forsterite), orthopyroxene $\left[92-95 \mathrm{Mg} \#=100 \mathrm{Mg} /\left(\mathrm{Mg}+\mathrm{Fe}^{2+}\right)\right]$ and chromite [69-73 Mg\#, and 68-95 Cr\# = $100 \mathrm{Cr} /(\mathrm{Cr}+\mathrm{Al})$ ] are found in the serpentinite dehydration runs containing only serpentinite as starting material $(R=0)$, but no interstitial glass can be detected (Figure 3A).

2) Bulk assimilation of the dehydrated serpentinite by the basaltic melt and production of homogeneous crystal-free hydrous basaltic melts $\left(\mathrm{L}_{\mathrm{bas}}\right)$ are consistently observed in the hybrid and mixed experiments with the highest proportions of basalt and the lowest proportions of serpentinite ( $R \geq 4$, Borisova et al., 2020a) in the starting material and with durations longer than $5 \mathrm{~h}$ at pressures of $0.2-1.0 \mathrm{GPa}$ (Figure 3B; Table 1; Supplementary Tables S2-S4).

3) The shortest hybrid runs at pressures of $0.5-1.0 \mathrm{GPa}$, and in all hybrid runs at $0.2 \mathrm{GPa}$ lasting for $0.5-120 \mathrm{~h}$ contain olivine-rich zone composed of high-Mg olivine, Cr-rich spinels and interstitial glasses $\left(\mathrm{L}_{\mathrm{int}}\right)$ (formerserpentinite zone or olivine-rich zone) and zone of hydrous basaltic glass (Figures 1C-E; Figure 2; Figure 3B; Table 1; Supplementary Tables S3, S4). The infiltration of basaltic melt into serpentinite at high basalt-to-serpentinite ratios $(\mathrm{R}=2.5-6.5)$, as simulated in the hybrid experiments, is able to generate new interstitial melts of intermediate to felsic composition 


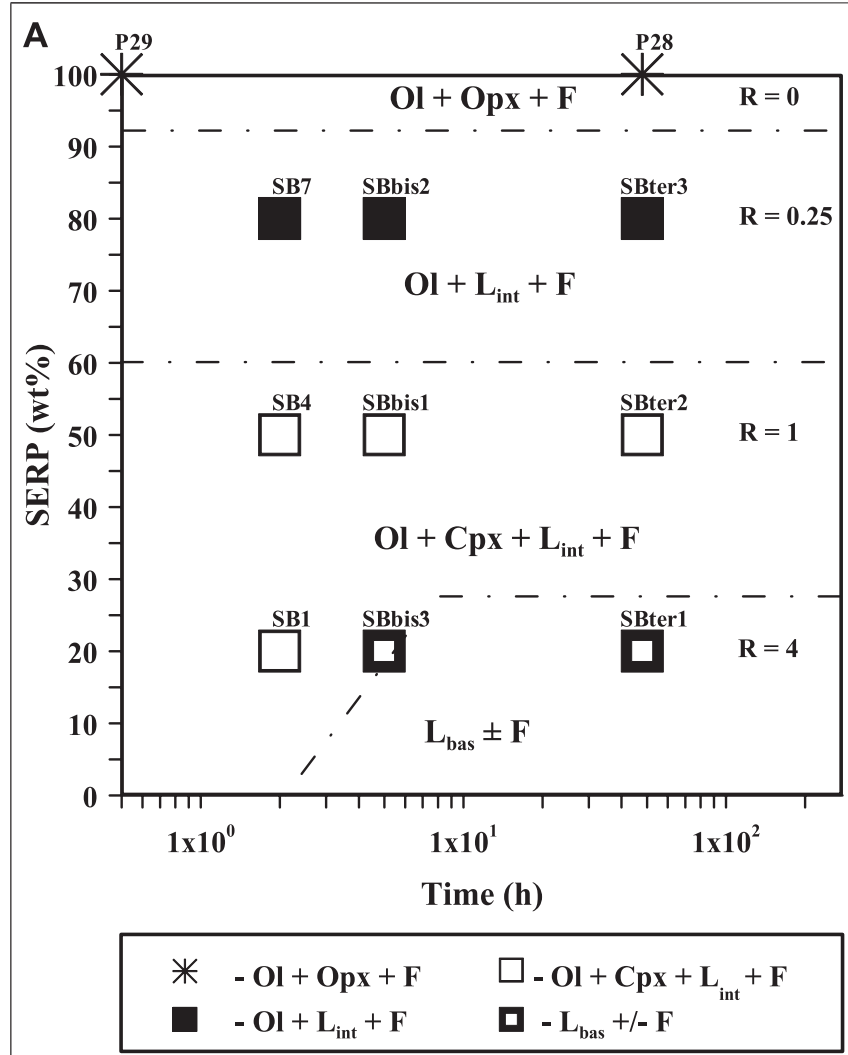

B

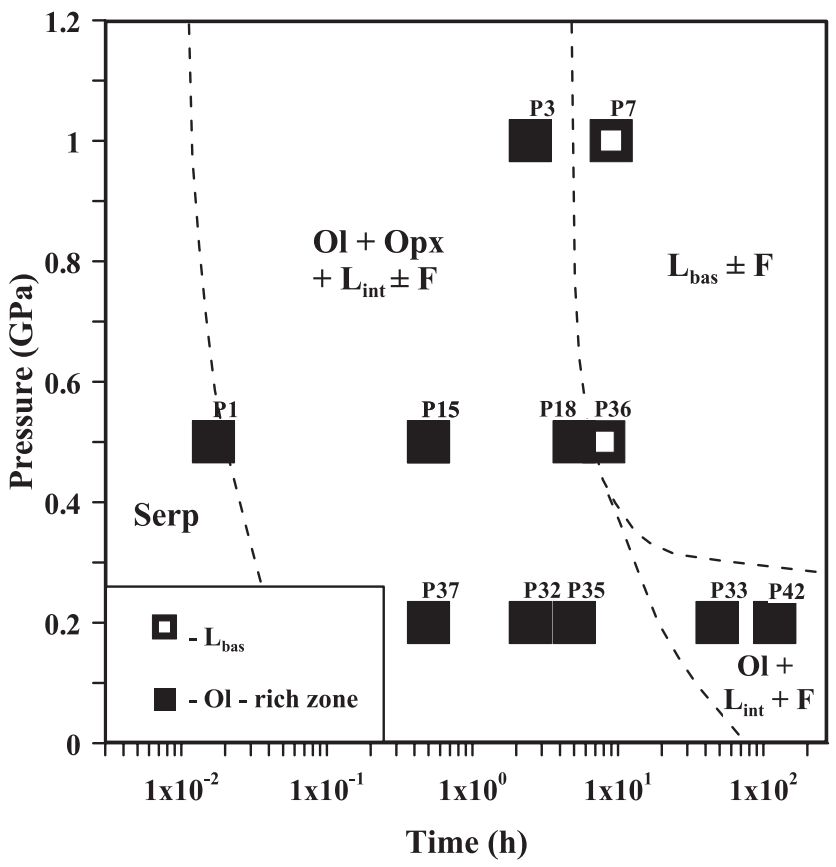

FIGURE 3 | (A) Phase compositions plotted as serpentine (SERP) proportion (in wt\%) vs. run duration (h) for the pure serpentinite dehydration experiments $(R=0)$ and mixed serpentinite-basalt reaction experiments at $0.2 \mathrm{GPa}$ and $1,250^{\circ} \mathrm{C}$ and basalt-to-serpentinite ratios $R=0.25,1$ and 4 . The diagram shows mineral, glass, and fluid phase associations observed after quenching. OI, Opx, Cpx, $\mathrm{L}_{\text {int }}$, $\mathrm{L}_{\text {bas }}$, and $\mathrm{F}$ stand for olivine,

(Continued)
FIGURE 3 | orthopyroxene, clinopyroxene, interstitial glass, basaltic glass, and fluid, respectively. All olivine-rich samples demonstrate the presence of chromite and chromiferous magnetite. The run numbers and corresponding experimental products with their compositions are further detailed in Supplementary Tables S2-S4. (B) Phase compositions plotted as pressure vs. run duration (h) for the hybrid serpentinite-basalt reaction experiments at $0.2-1.0 \mathrm{GPa}$ and $1,250-1,300^{\circ} \mathrm{C}$ and $R=2.5-6.5$. The diagram shows mineral, glass, and fluid phase associations observed in the olivine-rich zone after quenching. $L_{\text {bas }}$ is a unique zone of hydrous basaltic glass, while the olivine-rich zone contains residual serpentine minerals (Serp), predominant magnesian olivine $(\mathrm{Ol})$, and orthopyroxene $(\mathrm{Opx})$ in the interstitial glass $\left(\mathrm{L}_{\text {int }}\right)$, in the presence of fluid $(F)$ bubbles. All olivine-rich samples show the presence of chromite or chromiferous magnetite. $\mathrm{R}$ is the ratio of starting basaltic melt to serpentinite rock.

$\left(\mathrm{SiO}_{2}\right.$ contents ranging from 57 to $\left.67 \mathrm{wt} \%\right)$ in most hybrid $0.2 \mathrm{GPa}$ experiments. Only two shortest $(\leq 0.5 \mathrm{~h})$ of the $0.5 \mathrm{GPa}$ runs yield interstitial melts of intermediate composition $\left(\mathrm{SiO}_{2}=56-60 \mathrm{wt} \%\right)$, whereas the shortest $(2.5 \mathrm{~h}) 1.0 \mathrm{GPa}$ run generates interstitial melt of mafic composition $\left(\mathrm{SiO}_{2}=50 \mathrm{wt}\right.$ $\%)$. These results are in line with the fact that the combined effects of water, alkalis and low pressure on the structure of the aluminosilicate melt shift the equilibrium olivine-pyroxene cotectics to higher $\mathrm{SiO}_{2}$ contents (Kushiro, 1968; Hirschmann et al., 1998; Lundstrom, 2000).

4) Finally, a homogeneous and stable olivine-rich zone containing mostly high-Mg olivine (Fo $\left.{ }_{90-94}, \mathrm{~mol} \%\right)$, chromite (56-73 Mg\#, and 68-89 $\mathrm{Cr} \#$ ) and interstitial felsic glass is systematically observed in all mixed (SB series) time-series experiments with low basalt-toserpentinite ratios $(R=0.25-1.0)$ in the starting material, suggesting the formation of stable association of olivine, chromite and felsic melts at $0.2 \mathrm{GPa}$ (Figures 1A,B, 2, 3A, and 4; Supplementary Table S3).

\section{Interstitial Glass Composition and Equilibration With Minerals}

In the hybrid and mixed runs at $0.2-1.0 \mathrm{GPa}$, the olivine-rich zones host interstitial pockets of glass ranging in size from 10 to $200 \mu \mathrm{m}$, showing enrichment in silica (up to 66-71 wt\%), aluminum, alkalis and water (Figures 4, 5, Supplementary Tables S2-S4). The calculated chromite-olivine pair equilibration temperatures range from 1,222 to $1,261^{\circ} \mathrm{C}$ (Supplementary Table S2), in accordance with the runs temperature of $1,250{ }^{\circ} \mathrm{C}$, confirming an attainment of thermodynamic equilibrium between solid phases during experiments even if $\mathrm{Fe}-\mathrm{Mg}$ partition coefficients between olivine and the associated felsic melt range from 0.19 to 0.24 in the hybrid runs and from 0.08 to 0.25 in the mixed runs according to model of (Toplis, 2005), indicating a lack of Fe-Mg equilibrium between phases involving the felsic liquid (although such low values as 0.16 have been reported in alkali-rich systems). This variability may be at least partly due to quench artifacts. Indeed, the glass transition temperature of hydrous andesitic 


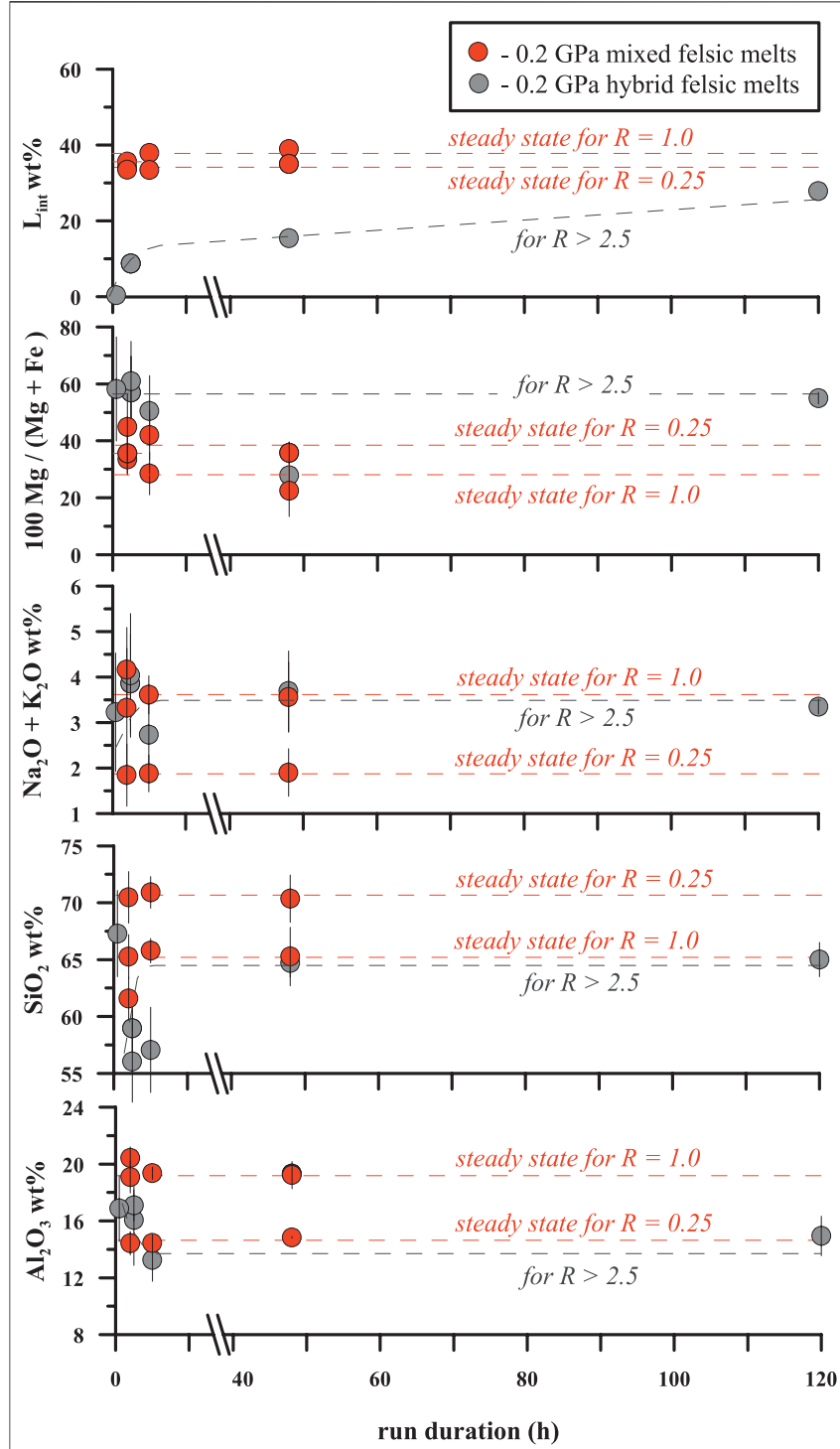

FIGURE 4 | Weight proportion of interstitial felsic melt (in wt\%), magnesium index $\left(100 \mathrm{Mg} /(\mathrm{Mg}+\mathrm{Fe})\right.$, total alkalis, $\mathrm{SiO}_{2}$ and $\mathrm{Al}_{2} \mathrm{O}_{3}$ (in wt\%) in the interstitial felsic melts of the time-series experiments vs. run duration (h). The oxide contents are recalculated to $100 \%$ on a volatile-free basis. $R$ is the mass ratio of starting basaltic melt to serpentinite rock (basalt-toserpentinite ratio). The dotted lines indicate compositional tendencies for the felsic melts of the mixed and hybrid runs. The mixed runs for given $\mathrm{R}$ values (0.25 and 1.0) are characterized by homogeneous interstitial felsic melts with constant $\mathrm{Si}, \mathrm{Al}$, and alkalis, while $\mathrm{L}_{\text {int }}$ proportions are independent of run duration. We argue for near equilibrium (steady) state of the produced felsic melts in assemblages with high-Mg olivine based on the mixed time-series experiments. Constant concentrations are established very early (in less than $2 \mathrm{~h}$ ) for $R=0.25$ and $R=1.0$ in the mixed runs, suggesting attainment of steady state or thermodynamic equilibrium of the run products. $X$ axis scale breaks from 12 to 40 .

melts with $\sim 5$ wt $\% \mathrm{H}_{2} \mathrm{O}$ is very low, $\mathrm{T}_{\mathrm{g}} \approx 300^{\circ} \mathrm{C}$ (e.g., Deubener et al., 2003). As a result, these melts are particularly sensitive to modification during quenching, thus contributing to the observed $\mathrm{Fe}-\mathrm{Mg}$ disequilibrium. Hybrid run samples P32, P33, and P42 yield olivine-felsic glass Fe-Mg partition coefficients of $0.24 \pm$ 0.13 , close to the theoretical range of $0.31 \pm 0.05$ (Toplis, 2005) (Supplementary Table S2), suggesting that the felsic melts are close to $\mathrm{Fe}-\mathrm{Mg}$ equilibrium with the associated olivine.

The major element composition of the glass produced in these experiments is mainly controlled by pressure, but also depends on the basalt-to-serpentinite initial ratio $(\mathrm{R})$ in the mixed runs. The glasses produced in the hybrid run lasting $2.5 \mathrm{~h}$ at $1.0 \mathrm{GPa}$ are mafic (50 wt $\% \mathrm{SiO}_{2}$ ), with an average $\mathrm{MgO}$ content of $10 \mathrm{wt} \%$, similar to the glasses produced in previous studies of equilibrium partial melting of hydrated peridotite at similar pressures (Ulmer, 2001). By contrast, generally higher $\mathrm{SiO}_{2}$ (57-71 wt\%, recalculated to $100 \%$ on a volatile-free basis) contents are found in glasses from all hybrid runs at $0.2 \mathrm{GPa}$, and from the mixed experiments at $0.2 \mathrm{GPa}$ with the highest proportion of serpentinite (50-80 wt\%; $R=0.25-1.0$ ), as well as those produced in short $(\leq 0.5 \mathrm{~h})$ runs at $0.5 \mathrm{GPa}$. For example, the mixed runs with the highest proportion of serpentinite $(80 \mathrm{wt} \%)$ and low basalt-to-serpentinite initial ratios $(R=0.25)$ produce dacite glasses with up to 70-71 wt\% $\mathrm{SiO}_{2}$ contents (Figures 4-6, Supplementary Table S3). Furthermore, the $0.2 \mathrm{GPa}$ glasses are enriched in alkalis (up to $3.9 \mathrm{wt} \% \mathrm{Na}_{2} \mathrm{O}+\mathrm{K}_{2} \mathrm{O}$ ), aluminum (up to $20.4 \mathrm{wt} \% \mathrm{Al}_{2} \mathrm{O}_{3}$ ) and chromium (up to $\sim 710 \mathrm{Cr}$ ppm) (Figures 5, 6; Supplementary Tables S3, S4).

The experimental glass composition obtained in the $0.2 \mathrm{GPa}$ mixed experiments is in an agreement with that obtained through modeling using MELTS at condition of the melts saturation with $\mathrm{H}_{2} \mathrm{O}$ fluid (Figures 5, 6; Supplementary Table S6). In the modeling, we used mixture of serpentinite with basalt in different proportions comparable to those observed in the mixed experiments (see Supplementary Material). The modeled phase proportions (e.g., melt proportions up to $35 \mathrm{wt}$ $\%$, Supplementary Table S6) and the mineral compositions are in agreement with those of the experimental ones (melt proportion up to $40 \mathrm{wt} \%$, Supplementary Table S2). For example, high-Mg olivine (91-93 mol\% Fo), chromite (20-45 mol\% of chromite molecule), aqueous fluid and Si-rich liquid (up to $61 \mathrm{wt} \% \mathrm{SiO}_{2}$ on anhydrous basis) appear in equilibrium assemblages at $1,250-1,300^{\circ} \mathrm{C}, \quad 0.2 \mathrm{GPa}$ and $\Delta \mathrm{QFM}+2$ to +3 in the models using a mixture of $80-95 \mathrm{wt} \%$ serpentinite and $20-5 \mathrm{wt} \%$ basalt, respectively. The felsic liquids contain up to $67 \mathrm{wt} \% \mathrm{SiO}_{2}$ if the composition of aqueous fluid is taken into consideration (Supplementary Table S6). Additionally, the MELTS liquids modelled at $0.2 \mathrm{GPa}$ (up to $61 \mathrm{wt} \% \mathrm{SiO}_{2}$ on anhydrous basis) are richer in $\mathrm{SiO}_{2}$ than those modelled at $0.5-0.9 \mathrm{GPa}$ (up to $55-59 \mathrm{wt} \% \mathrm{SiO}_{2}$ on anhydrous basis) (Supplementary Table S6), confirming our experimental observations at 0.5 and $1.0 \mathrm{GPa}$.

To evaluate the result of energy constrained interaction between serpentinite and basalt, we have performed Magma Chamber Simulator (MCS, Bohrson et al., 2014; Bohrson et al., 2020; Heinonen et al., 2020) modeling in the range from 0.1 to $0.5 \mathrm{GPa}$ at condition of the magma saturation with $\mathrm{H}_{2} \mathrm{O}$ fluid (Supplementary Table S7). The MCS modeled liquid composition is in excellent agreement with that of the experimental felsic melts (Figures 5, 6). The only exception is $\mathrm{Mg}$ index, but this is likely related to the $\mathrm{Fe}-\mathrm{Mg}$ re-equilibration of 


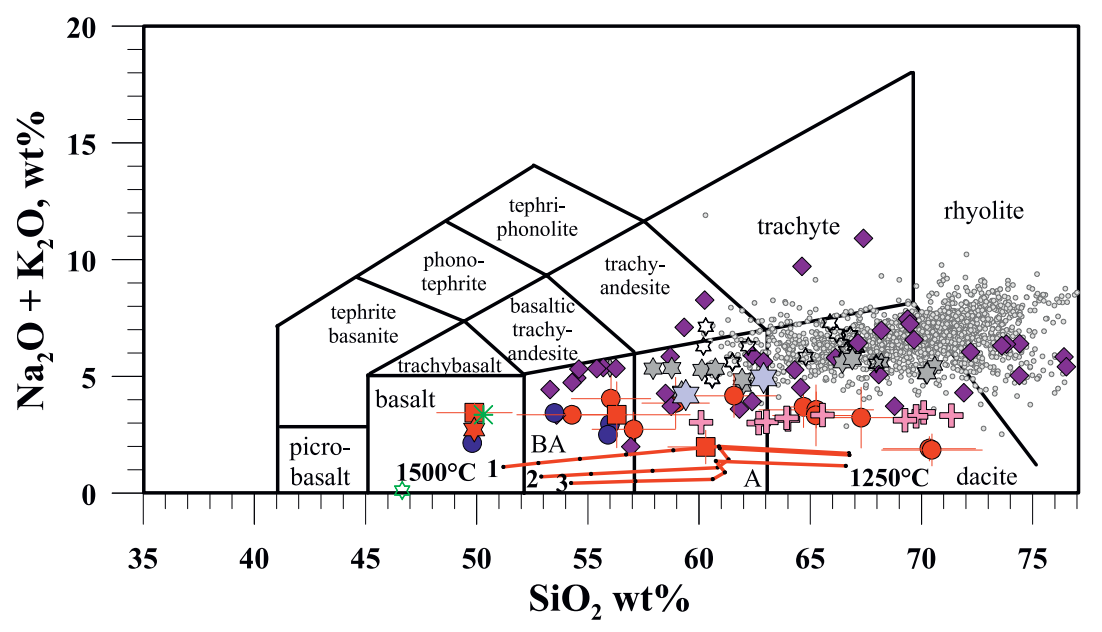

* - starting basalt, this work

$s^{3}$ - starting serpentinite, this work

- 0.1 MPa melts

- 0.2 GPa meas. melts, this work

- $0.5 \mathrm{GPa}$ hybrid melts, this work

- 1.0 GPa hybrid melts, this work

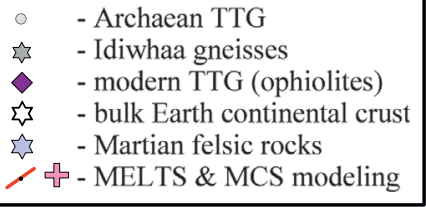

FIGURE 5 | Sum of alkali oxides (in wt\%) vs. $\mathrm{SiO}_{2}$ (in wt\%) in interstitial glasses produced during hybrid and mixed runs of serpentinite-basalt interaction plotted in the classification diagram of Le Maitre (2002). The major element compositions of the measured ("meas. melts", red dots are recalculated to 100\% on a volatile-free basis). The error bars reflect the felsic glass heterogeneity compared to the mean values. The glass compositions are compared with the starting basalt and serpentinites, the anhydrous 0.1 MPa experimental glasses (Fisk, 1986), modern TTG or plagiogranites in mantle section of ophiolites (Amri et al., 1996, 2007; Shervais, 2008; Xu et al., 2017), the bulk Earth continental crust (Wedepohl, 1995; Rudnick and Gao, 2003), Archaean TTG (Moyen and Martin, 2012), Acasta Gneiss Complex rocks (Idiwhaa gneisses) (Reimink et al., 2016), Martian felsic rocks (Sautter et al., 2016). BA, basaltic andesite; A, andesite. Red lines with black points correspond to the thermodynamic modeling using MELTS of equilibrium liquids coexisting with mixture of 80-95 wt\% serpentinite with $20-5$ wt\% basalt ( $R<1)$ at 0.2 GPa and different temperatures ranging from $1,500^{\circ} \mathrm{C}$ to $1,250^{\circ} \mathrm{C}$ and redox conditions of $\left.\Delta Q F M+2: 1\right) 80$ wt $\%$ serpentinite and 20 wt $\%$ basalt $\left.(R=0.25) ; 2\right) 90$ wt $\%$ serpentinite and 10 wt $\%$ basalt $(R=0.11)$, and 3) $95 \mathrm{wt} \%$ serpentinite and $5 \mathrm{wt} \%$ basalt $(R=0.05)$ (Supplementary Table S6). The compositions modeled at $1,250^{\circ} \mathrm{C}$ are corrected according to $\mathrm{SiO}_{2}$ contents of 6 wt\% $\mathrm{SiO}_{2}$ in the aqueous fluid (Supplementary Tables S5, S6). Pink crosses correspond to the Magma Chamber Simulator (MCS) modeling results of equilibrium liquid appearing upon the interaction between the serpentinite and basalt at different basalt-to-serpentinite mass ratio, $R$, different temperatures of the serpentinite rock $\left(1,100-1,300^{\circ} \mathrm{C}\right)$ and pressures from 0.1 to $0.5 \mathrm{GPa}$ at conditions of the magma saturation with $\mathrm{H}_{2} \mathrm{O}$ fluid $($ Supplementary Table S7).

the experimental liquids with the predominant olivine upon quenching.

\section{DISCUSSION}

\section{Felsic Melt Formation}

The measured glass compositions vary from basaltic andesite to dacite, which is consistent with the general tendency of olivinesaturated partial melts to become progressively richer in $\mathrm{SiO}_{2}$ with decreasing pressure and increasing water content (e.g., Hirschmann et al., 1998). Additionally, it is widely known that water fluid expands the thermodynamic stability of forsterite-rich olivine (e.g., Green, 1973; Nicholls et al., 1973) and chromite (Veksler and Hou, 2020). Thus, it is not surprising that high-Mg olivine in association with chromite is recorded in equilibrium with felsic melts of dacitic composition in our low-pressure experiments $(0.2 \mathrm{GPa})$. Most glasses produced at $0.2 \mathrm{GPa}$ are richer in $\mathrm{Si}, \mathrm{Al}$, and alkalis than dry glasses produced at $0.1 \mathrm{MPa}$ (Fisk, 1986) as well as nearly dry glasses produced at $0.5 \mathrm{GPa}$ (Kelemen et al., 1995). The hydrous intermediate to felsic melts produced in our experiments are likely formed by the fertilization of olivine-rich zones due to the presence of aqueous fluids produced by the interaction of serpentinite and basaltic melt at $0.2-1.0 \mathrm{GPa}$. At lower pressures, this process is associated with the incongruent melting of harzburgite producing olivine at the expense of orthopyroxene. Indeed, according to Kushiro (1968), Shaw (1999), Shaw et al. (1998), Lundstrom (2000), Shaw and Dingwell (2008), and Borisova et al. (2020a) silica-rich liquids may be formed via orthopyroxene dissolution during meltperidotite interactions. The presence of polyhedral and mainly unzoned olivine crystals, co-existing with homogeneous interstitial felsic melt in the olivine-rich zone of the longest runs (Figure 2; Table 1; Supplementary Table S2), supports the growth of new olivine that attains equilibrium with the melt at $1,250^{\circ} \mathrm{C}$ and $0.2 \mathrm{GPa}$.

A steady state is established within less than $2 \mathrm{~h}$ after the start of reaction in the mixed runs (Figures 3, 4). The fluid-present reaction leads to the formation of high- $\mathrm{Mg}$ olivine + chromite + felsic melt. Note that the composition of the interstitial felsic melt produced in this way is a function of the basalt-to-serpentinite mass ratio $(R)$. High and constant $\mathrm{SiO}_{2}$ contents $(70-71 \mathrm{wt} \%$, 


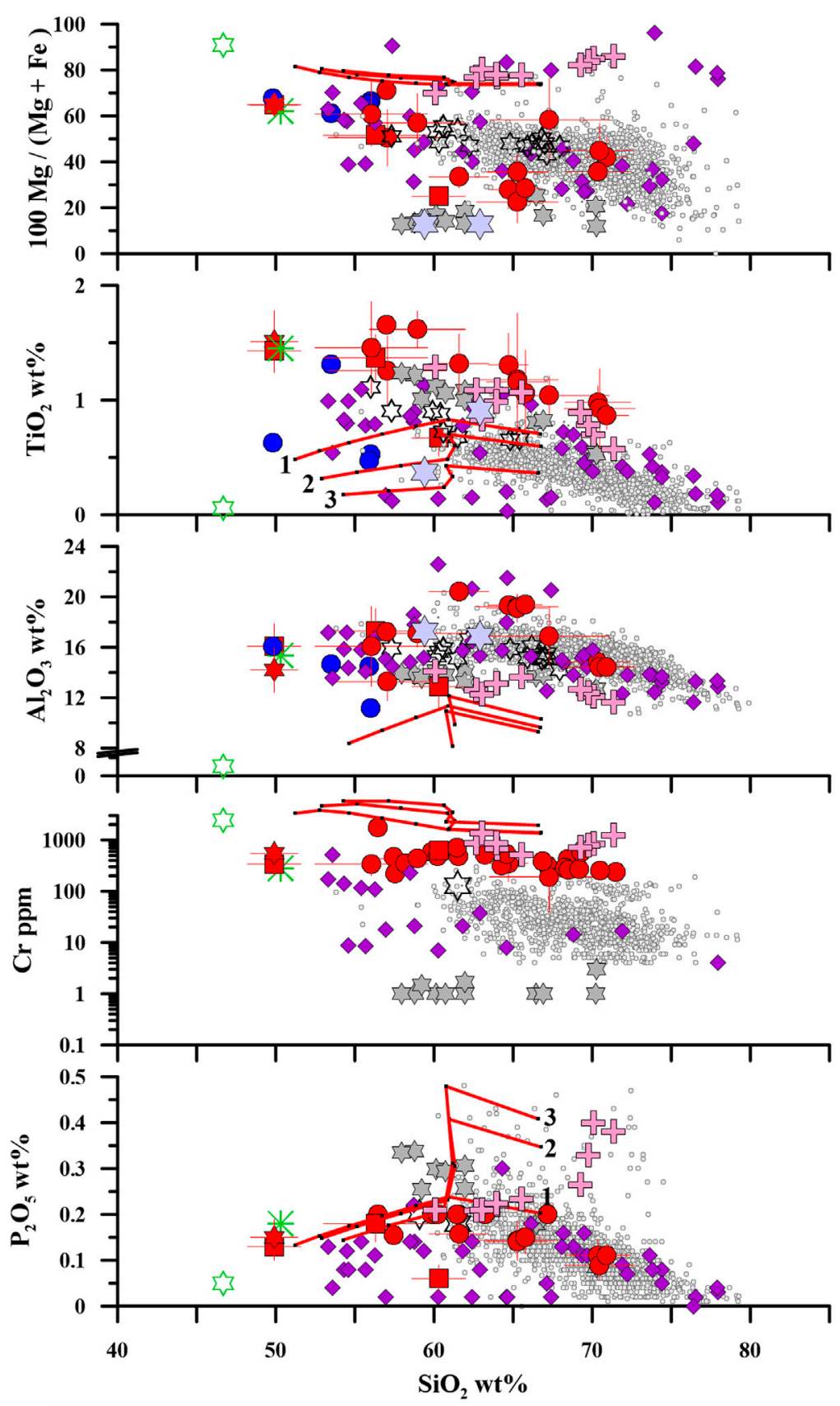

\begin{tabular}{|c|c|c|c|}
\hline & - starting BAS, this work & ○ & - $0.1 \mathrm{MPa}$ melts \\
\hline$\sum$ & - starting SERP, this work & $\circ$ & - Archaean TTG \\
\hline & - $0.2 \mathrm{GPa}$ meas. melts, this work & $\xi$ & - Bulk CC \\
\hline 品 & - $0.5 \mathrm{GPa}$ hybrid melts, this work & 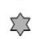 & - Idiwhaa gneisses \\
\hline 2 & - 1.0 GPa hybrid melts, this work & $\diamond$ & - modern TTG (ophiolites) \\
\hline & MELTS \& MCS modeling & s & - Martian felsic rocks \\
\hline
\end{tabular}

FIGURE 6 | Magnesium index (100 Mg/(Mg + Fe)), major and minor Ti, $\mathrm{Al}, \mathrm{P}$ oxides (in wt\%), and $\mathrm{Cr}$ (in ppm) vs. $\mathrm{SiO}_{2}$ (in wt\%) in interstitial glasses produced at 0.2-1.0 GPa during serpentinite-basalt interaction of hybrid and mixed runs. The major element compositions of the measured (meas.) melts are recalculated to $100 \%$ on a volatile-free basis. The error bars reflect the felsic glass inter-sample heterogeneity compared to the mean values (Supplementary Tables S3, S4). The glass composition is compared to the starting basalt (BAS) and serpentinite (SERP), the anhydrous 0.1 MPa experimental glasses (Fisk, 1986), modern TTG (plagiogranites) in mantle sections of ophiolites (Amri et al., 1996, 2007; Shervais, 2008; Xu et al., 2017), the bulk Earth continental crust (Bulk CC) (Wedepohl, 1995; 
FIGURE 6 | Rudnick and Gao, 2003), Archaean TTG (Moyen and Martin, 2012), Acasta Gneiss Complex rocks (Idiwhaa gneisses) (Reimink et al., 2016) and Martian felsic rocks (Sautter et al., 2016). Both EPMA and LA-ICP-MS data for the $0.2 \mathrm{GPa}$ felsic melts are used to determine the Cr concentrations of hybrid melts, whereas only EPMA data are used for the P contents (Supplementary Table S3). Red lines labelled 1, 2 and 3 with black points correspond to the thermodynamic modeling using MELTS of equilibrium liquids coexisting with mixture of $80-95 \mathrm{wt} \%$ serpentinite with $20-5 \mathrm{wt} \%$ basalt $(R<1)$ at $0.2 \mathrm{GPa}$ and different temperatures ranging from $1,500^{\circ} \mathrm{C}$ to $1,250^{\circ} \mathrm{C}$ and redox conditions of $\left.\triangle \mathrm{QFM}+2: 1\right) 80 \mathrm{wt} \%$ serpentinite and $20 \mathrm{wt} \%$ basalt $\left.(R=0.25) ; 2\right) 90 \mathrm{wt} \%$ serpentinite and $10 \mathrm{wt} \%$ basalt $(R=0.11)$ and 3$) 95 \mathrm{wt} \%$

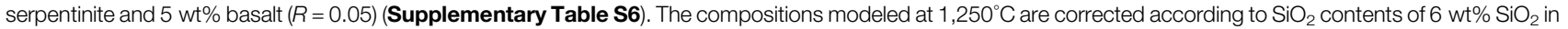
the aqueous fluid (Supplementary Tables S5, S6). Pink crosses correspond to the Magma Chamber Simulator (MCS) modeling results of equilibrium liquid appearing upon the interaction between the serpentinite and basalt at different basalt-to-serpentinite mass ratio, $R$, different temperatures of the serpentinite rock $\left(1,100-1,300^{\circ} \mathrm{C}\right)$ and pressures from 0.1 to $0.5 \mathrm{GPa}$ at conditions of the magma saturation with $\mathrm{H}_{2} \mathrm{O}$ fluid (Supplementary Table S7).

recalculated to $100 \%$ on a volatile-free basis) are observed in the felsic melts at the lowest $R$ of 0.25 . For the run series with $R=1.0$, clinopyroxene is an additional stable crystalline phase formed in association with high-Mg olivine, chromite and felsic melt. Remarkably, the proportions of interstitial melt (33-40 wt\%), as well as the concentrations of $\mathrm{SiO}_{2}, \mathrm{Al}_{2} \mathrm{O}_{3}$, and alkalis $\left(\mathrm{Na}_{2} \mathrm{O}+\right.$ $\mathrm{K}_{2} \mathrm{O}$ wt\%) in the melt, remain constant over a wide range of $\mathrm{R}$ (0.25-1.0) throughout the whole run duration (Figure 4). The $\mathrm{Mg} /(\mathrm{Mg}+\mathrm{Fe})$ index of the melt may be affected by Fe-Mg exchange with olivine and chromite during quenching.

The MCS modeling data demonstrate that i) after the serpentinite addition, $\mathrm{SiO}_{2}$ content in the equilibrated liquid increases with decreasing pressures (Supplementary Table S7). ii) The lower basalt-to-serpentinite (R) mass ratio increases the $\mathrm{SiO}_{2}$ content in the equilibrated melt (Figures 5, 6). In MCS results there is a massive crystallization event following the reaction with serpentinite, but the following crystallization will be discussed in a future paper. iii) The lower the temperature of the serpentinite, the higher the $\mathrm{SiO}_{2}$ increase in the equilibrated liquid. This is a good outcome since the experiments cannot really realistically reproduce the lower temperature of the serpentinite. iv) Having $\mathrm{Cr}$ in the initial serpentinite rock also increases the $\mathrm{SiO}_{2}$ in the equilibrated liquid. Both thermodynamic models (MELTS and MCS) suggest that the mineral association observed in the $0.2 \mathrm{GPa}$ mixed experiments is near thermodynamic equilibrium.

\section{Aqueous Fluid Composition}

In all hybrid and mixed experiments at 0.2 and $0.5 \mathrm{GPa}$, fluid bubbles are present, likely produced by serpentinite decomposition. Therefore, we conducted thermodynamic modelling of the element solubility in the aqueous fluid phase (Supplementary Material), which provides an independent qualitative support for our conclusions drawn from the analysis of the run products described above (e.g., interstitial felsic glasses). Modeling shows that the aqueous fluid generated by serpentinite dehydration in the presence of basaltic melt is systematically enriched in $\mathrm{Si}, \mathrm{Al}, \mathrm{Na}$, and $\mathrm{K}$ (Supplementary Table S5) compared to both the initial and reacted serpentinite (olivine-rich zone, see above). The major mineral phases predicted to form at equilibrium are olivine and orthopyroxene, together with minor amounts of clinopyroxene and feldspar-like glass phases, are in good agreement with those observed in most hybrid and mixed experiments. The calculations predict high-Mg olivine ( Fo $\left._{93-96} \mathrm{~mol} \%\right)$ and orthopyroxene (Mg\# 94-96) compositions, which are within the range analyzed in the hybrid run products (Supplementary Table S3, S4), suggesting local thermodynamic equilibrium was attained between the fluid and these minerals.

The aqueous fluid in mixed and hybrid experiments is predicted to be enriched in Si (up to $6 \mathrm{wt} \%$ ), $\mathrm{Na}$ (up to $4 \mathrm{wt} \%$ ), $\mathrm{K}$ (up to $0.4 \mathrm{wt} \%$ ), and $\mathrm{Al}$ (up to $0.2 \mathrm{wt} \%$ ), with other elements being much less abundant $(\mathrm{Mg}, \mathrm{Ca}, \mathrm{Fe}$ typically $<\sim 10 \mathrm{ppm})$. Increasing the pressure from 0.2 to $1.0 \mathrm{GPa}$ generally results in an increase of all element concentrations in the fluid, in agreement with the increase of water solvent density and water solvation power (e.g., Pokrovski et al., 2013). A similar systematic order of decreasing concentration in the fluid is maintained over the whole range of pressures and basalt-to-serpentinite initial ratios: $\mathrm{Si}>\mathrm{Na}>$ $\mathrm{K}>\mathrm{Al}>>\mathrm{Fe}>\mathrm{Ca}>\mathrm{Mg}$. This finding strongly suggests that intrinsic uncertainties in the thermodynamic model are unlikely to obscure the large amplitude of general trends. The low concentrations of $\mathrm{Fe}$ and $\mathrm{Ca}$ (typically 100 to 10,000 times less abundant than $\mathrm{Si}, \mathrm{Na}, \mathrm{K}$ or $\mathrm{Al})$, and in particular of $\mathrm{Mg}\left(10^{6}-10^{8}\right.$ less abundant than Si, Supplementary Table S5), are in agreement with the typical order of elemental abundance in natural hydrothermal-magmatic fluids of relatively low salinity as inferred from fluid inclusions (e.g., Kouzmanov and Pokrovski, 2012; references therein). This is corroborated by our experimental results, providing evidence for major transfer of $\mathrm{Si}, \mathrm{Na}, \mathrm{K}$, and $\mathrm{Al}$ from basalt and serpentinite to felsic melts. Remarkably, the Si/Mg ratio $\left(\sim 10^{6}-10^{10}\right)$ in the fluid phase predicted by calculations systematically increases by almost 1,000 times with decreasing pressure from 1 to $0.2 \mathrm{GPa}$ (Supplementary Table S5). Even though our calculations are semi-quantitative at such extreme conditions for the fluid phase (see Supplementary Material), this large relative change is an additional indication that relatively low pressures should favor the enrichment of both fluid and melt phases in Si relative to "mafic" elements $(\mathrm{Mg})$ in water-present systems, thus promoting the formation of felsic (i.e. Si-rich) melts quenched to glasses, as observed in our direct experiments.

\section{Compositional Features of Interstitial Glasses}

The intermediate to felsic glasses from the hybrid and mixed runs were analyzed not only for major and minor $(\mathrm{Cr}, \mathrm{Ni})$ but also for trace elements (Supplementary Material). Figure 7 demonstrates incompatible trace element compositions (normalized to the primitive mantle) of the interstitial felsic glasses. The positive $\mathrm{Pb}$ anomaly relative to light rare earth 


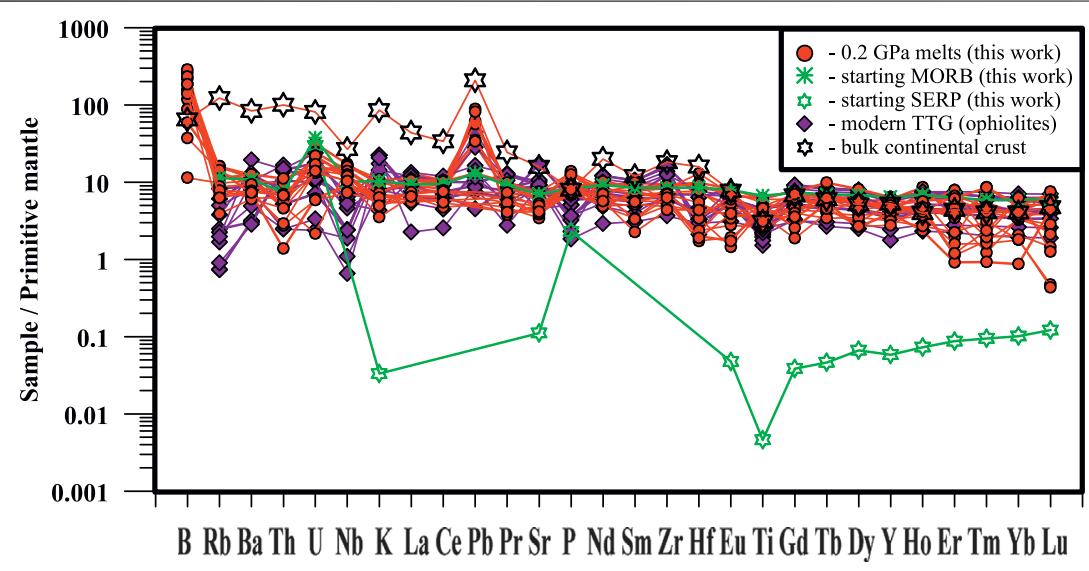

FIGURE 7 | Primitive mantle-normalized trace element abundance patterns of felsic glasses produced at 0.2 GPa during serpentinite-basalt interaction. The primitive mantle composition is after (Sun and McDonough, 1989) and (Lyubetskaya and Korenaga, 2007) for B only. The felsic glass composition is compared to basalt (starting MORB) and serpentinite (starting SERP), modern TTG (Amri et al., 1996, 2007; Shervais, 2008; Xu et al., 2017), the bulk continental crust after Wedepohl (1995).

elements (LREE) observed in felsic glasses is an important signature of typical continental rocks compared to mantlederived magmas (Rudnick and Gao, 2003). The incompatible trace element patterns of the felsic glasses are nearly identical to those of modern TTG (plagiogranite) rocks found in the mantle sections of ophiolites (Amri et al., 1996; 2007; Shervais, 2008; Xu et al., 2017). The felsic glasses produced in runs at $0.2 \mathrm{GPa}$ have major and trace element contents ( $\mathrm{Si}, \mathrm{Ti}, \mathrm{Al}, \mathrm{Mg}, \mathrm{Ca}, \mathrm{Na}, \mathrm{K}, \mathrm{P}$, and $\mathrm{Cr}, \mathrm{REE})$, as well as $\mathrm{Mg} /(\mathrm{Mg}+\mathrm{Fe})$, that share some similarities with modern TTG situated in the mantle sections of ophiolites (Figures 5-7). The $0.2 \mathrm{GPa}$ intermediate to felsic melts are characterized by lower $\mathrm{SiO}_{2}$ and $\mathrm{Na}_{2} \mathrm{O}+\mathrm{K}_{2} \mathrm{O}$ contents and higher $\mathrm{Cr}$ contents compared with Archaean TTG rocks (Figures 5, 6). The slight enrichment in LREE of the felsic glasses produced in our experiments differs from the strongly fractionated patterns of Archaean tonalite-trondhjemitegranodiorite (TTG) suites (Moyen and Martin, 2012). This is in line with the conditions of shallow felsic crust formation by a mechanism distinct from the "sagduction" or plate subduction operating during the Archaean (Moyen and Martin, 2012). At similar $\mathrm{SiO}_{2}$ contents, the higher $\mathrm{Mg}$ index and $\mathrm{Cr}$ contents (up to $1,400 \mathrm{Cr}$ ppm) in the experimental felsic glasses produced at $0.2 \mathrm{GPa}$ contrast strongly with the $4.02 \mathrm{Ga}$ Idiwhaa gneisses, northwest Canada (Figure 6), suggesting that the Hadean Acasta Gneiss Complex magmas did not form due to reaction of serpentinite with basaltic melts. Except for fluid-mobile B and $\mathrm{Pb}$, the trace element compositions of the $0.2 \mathrm{GPa}$ interstitial felsic glasses are similar to those of the starting basaltic melt (Figure 7). Additionally, hafnium contents (0.5-4.0 ppm Hf) and $\mathrm{Lu} / \mathrm{Hf}$ ratios $\left[\mathrm{Lu}_{\mathrm{N}} / \mathrm{Hf}_{\mathrm{N}}=0.11-2.2\right.$, normalized to the primitive mantle composition of Sun and McDonough (1989)] in the $0.2 \mathrm{GPa}$ felsic melts are similar to those of the starting basaltic melt (2.7 ppm and 0.7, respectively), suggesting that the experimental melts might have inherited their trace element and Hf isotope signatures from a precursor basaltic reservoir (Supplementary Table S3).

\section{GEOLOGICAL SIGNIFICANCE}

\section{Shallow Felsic Crust Production by Melting of Serpentinized Peridotite}

Our study provides new insight into potential mechanisms of intermediate to felsic crust formation. Serpentinized peridotites and mafic cumulates are the most abundant constituents of the modern slow-spreading oceanic lithosphere at the level of the Moho mantle-crust boundary (Cannat, 1993). Cyclic magmatic and hydrothermal processes in the modern Earth likely lead to the generation of intermediate to felsic material within the peridotitic lithosphere below spreading centers at high temperature and shallow $(<10 \mathrm{~km})$ depths. These processes include repeated intrusions of mantle-derived basaltic magmas (O'Hara and Mathews, 1981; Amri et al., 1996; 2007; Borisova et al., 2012), where reactions are possible between hot basaltic melts and a previously formed cold hydrated ultramafic lithosphere during periods of low magma supply and oceanic water circulation at shallow depth (Figure 8). The melting of serpentinized peridotite produced in our experiments leads to the formation of dunitewehrlite- or chromitite-type rocks (Figures 1-3A,B) similar to their natural analogues described in ophiolites (e.g., Dick, 1977; Benoit et al., 1999; Borisova et al., 2020c; Zagrtdenov et al., 2018; Rospabé et al., 2019; Borisova et al., 2020b). Our experimental data thus support an empirical model for the reaction between hydrated mantle and basaltic magma inferred from natural data on chromite-hosted inclusions from the Oman ophiolite (Borisova et al., 2012). The olivine-rich aggregates containing interstitial hydrous silica-saturated liquids are gravitationally unstable, like those obtained in our experiments. This is because of the high density contrast between hydrous felsic melts $\left(<2.4 \mathrm{~g} / \mathrm{cm}^{3}\right.$, Supplementary Table S6) and mafic silicate minerals $\left(3.2-3.3 \mathrm{~g} / \mathrm{cm}^{3}\right)$ and chromite $\left(\sim 5.0 \mathrm{~g} / \mathrm{cm}^{3}\right)$, while melt mobility is also favored by low viscosity. With reference to processes occurring at oceanic spreading centers (Amri et al., 1996, 2007; Benoit et al., 1999), which lead to the formation of 

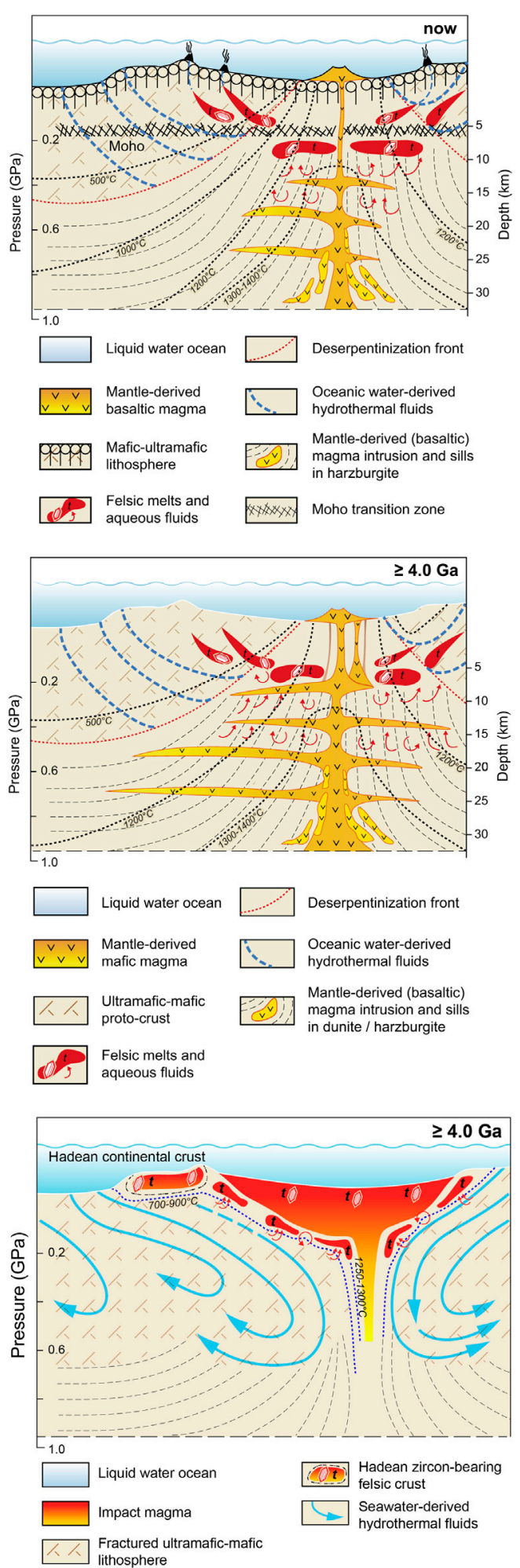

FIGURE 8 | Upper panel: Model for the formation of shallow felsic crust in mantle peridotites of the oceanic lithosphere. Dehydration is initiated by the intrusion of mantle-derived magmas into hydrated (serpentinized) mantle. The released fluid promotes fertilization and partial melting of the peridotite, which leads to production of TTG magmas

(Continued)
FIGURE 8 | marked as " $t$ ". The generated melts forms intrusive bodies in the host peridotite and overlying crust at shallow depths $<10 \mathrm{~km}$. Black dotted lines correspond to isotherms. The horizontal scale of the model is $\sim 30 \mathrm{~km}$. The depths on the vertical scale are calculated assuming a serpentinite density of $3 \mathrm{~g} / \mathrm{cm}^{3}$. Middle panel: Model for the formation of the Hadean felsic crust due to activity of either a heat-pipe or a proto-rift volcanoes. Dehydration is initiated by the intrusion of mantle-derived magmas into (ultra-)mafic protocrust. The released fluids promote partial melting of the peridotite, which produces felsic (e.g., tonalite) magmas marked as " $t$ ". The generated melts form intrusive bodies in the host peridotite protocrust at shallow depths $<10 \mathrm{~km}$. Black dotted lines correspond to isotherms. The horizontal scale of the model is $\sim 30 \mathrm{~km}$. The depths on the vertical scale are calculated assuming a serpentinite density of $3 \mathrm{~g} / \mathrm{cm}^{3}$. Lower panel: Model of impact formation of felsic crust on the early Earth and Mars. Impact-induced melting of the hydrated ultramaficmafic protocrust promotes fertilization and partial melting of the peridotite. The (ultra-) mafic protocrust is hydrated through hydrothermal circulation due to contact with seawater. The partial melting produces intermediate to felsic (tonalite and/or granodiorite) magmas marked as " $t$ ". The production of intermediate to felsic melts may occur when the predominant proportion of serpentinite in the hybrid system is above 50 wt\% $(R \leq 1)$. The generated melts form an impact body at shallow depths $<10 \mathrm{~km}$. Blue dotted lines correspond to isotherms. The horizontal scale of the model is $\sim 30 \mathrm{~km}$.

ophiolites, low-density hydrous felsic melts generated below and/ or at the Moho transition zone are collected in decimeter to meter sized pods and veins which then progressively coalesce into larger intrusions in the shallow oceanic lithosphere. Alternatively, the felsic melts produced by aqueous fluid-assisted partial melting of peridotite may remain scattered in peridotites at shallow depths $<10 \mathrm{~km}$, as shown by olivine-hosted melt inclusions in peridotite xenoliths (Hirschmann et al., 1998). If segregation into intrusions takes place, cooling (e.g., due to hydrothermal circulation) will result in crystallization of these hydrous felsic liquids. In addition to the generation of low-temperature plagiogranite magmas in the oceanic crust due to partial melting of hydrated gabbros (Koepke et al., 2004), we suggest that high-temperature plagiogranites melts and magmas (or high-temperature TTG) may be formed through aqueous fluid-assisted partial melting of serpentinized peridotite.

\section{Implications for the Early Earth}

Hydrated peridotite, and its isochemical analogue serpentinite, has been suggested to be a major shallow component of the Hadean and Noachian protocrusts on Earth and Mars (Albarède and Blichert-Toft, 2007; Elkins-Tanton, 2012), being the result of the interaction of seawater-derived fluids with peridotites (Guillot and Hattori, 2013). Indeed, planets like Earth and Mars were massive enough to allow the formation of an early ultramafic (peridotite-like, silica-poor) magma ocean, while the distance from the Sun and the surface temperature were appropriate for the existence of an ocean of liquid water (Valley et al., 2002; Albarède and Blichert-Toft, 2007; Müntener, 2010). It is widely recognized (Albarède and Blichert-Toft, 2007; Elkins-Tanton, 2012) that magma ocean(s) underwent solidification to produce shallow ultramafic-mafic protocrust during the earliest stages of planetary evolution. However, it remains unclear how early Hadean crustal rocks could have generated quartz-normative to quartz-saturated magmas of intermediate to 
felsic composition. Direct natural evidence for the precursor of Hadean ( $\geq 4 \mathrm{Ga}$ ) felsic crust is scarce, and remains the subject of intense debate (Wedepohl, 1995; Rudnick and Gao, 2003; Harrison, 2009; Reimink et al., 2014, 2016; Burnham and Berry, 2017; Bell et al., 2018). Investigations of the 4.37-4.02 Ga Jack Hills detrital zircon crystals (JHZ), which are the oldest remnants of primordial felsic magmas on Earth, support the existence of a felsic crust during the earliest stages of the Hadean eon (Cavosie et al., 2006; Harrison, 2009; Burnham and Berry, 2017). Either reworking into younger crust or recycling of the Hadean crust into the mantle have been proposed to explain the lack of remnants of the earliest felsic crust on Earth (O’Neil and Carlson, 2017; Nédélec et al., 2017). However, studies of the Jack Hills zircon crystals allow to infer the presence of an igneous protolith that had experienced low-tomoderate temperature alteration by aqueous fluids, thereby ruling out a sedimentary source (Burnham and Berry, 2017; Whitehouse et al., 2017), although alternative opinions still exist (Harrison, 2009; Bell et al., 2018).

We propose that basaltic melts were introduced in the primitive ultramafic protocrust at the very end of the crystallization of the magma ocean, and/or by heat-pipe volcanoes through a stagnant lid (Moore and Webb 2013), during the earliest stages of Earth evolution, or as proto-rifts at the end of the Hadean (Capitanio et al., 2020). Unfortunately, no traces of Hadean tectonic regimes survived so far. Thus, we propose here that the basaltic melts were intruded into an ultramafic protocrust, initiating dehydration processes. The released fluids promoted fertilization and partial melting of the peridotite, which in turn led to the production of tonalitegranodiorite magmas forming intrusive bodies in the peridotite protocrust at shallow depths $<10 \mathrm{~km}$ (Figure 8). The segregation of felsic melts in the upper protocrust was favored by lithospheric hydraulic fracturing and the low density of the hydrous melts, with high melt proportions (up to 33-40 wt\%, Supplementary Table S2) corresponding to high liquid volume fractions $(\varphi)$ of $\sim 37-45$ vol\%. Alternatively, the generation of such intermediate to felsic melts and magmas at shallow depths within the early ultramafic-mafic protocrust may also have been possible due to impact-induced melting (Marchi et al., 2014), particularly if the proportion of serpentinite was above $50 \mathrm{wt} \%$ in the hybrid system $(R \leq 1)$. Such melting would have favored intense mixing of shallow hydrated ultramafic and mafic components at high temperature (as modelled in our mixed experiments), well above the liquidus of basalt before the onset of modern plate tectonics (Figure 8).

\section{Implications for Early Mars}

The proposed mechanism of the aqueous fluid-assisted partial melting of peridotite may have led to the formation of a shallow felsic (continental) crust on other rocky planets such as Mars, provided liquid water or a volatile element-rich magma ocean was present at an early stage of their evolution. The finding of ancient serpentinites at the surface of Mars (Ehlmann et al., 2010) suggests that serpentinite formation and aqueous fluid-assisted melting of serpentinized peridotite may be envisaged during the earliest history of this planet. There is also evidence for a
4.43-4.13 Ga-old granodioritic and/or tonalitic crustal component on early Mars (Sautter et al., 2015; Sautter et al., 2016). These quartz-normative rocks, which are believed to represent the early Martian continental crust, cannot be produced from partial melting of the mantle and subsequent fractional crystallization (Sautter et al., 2015; Sautter et al., 2016). By contrast, recent modeling using the MELTS software (Udry et al., 2018) suggests that the felsic rocks of Gale crater were produced by the accumulation/fractionation of feldspar from basaltic melt; however, these authors make no comparison with modern TTG (plagiogranite) rocks. Our data demonstrated on Figures 5, 6 are also in line with our model and suggest that the Noachian granodiorite (felsic) rocks on Mars may have been produced by aqueous fluid-assisted partial melting of peridotite induced by reaction with basaltic melts. Survival of the primary intermediate to felsic liquids and formation of a solid crust may have been possible if the effects of gravitational overturn were limited (Elkins-Tanton, 2012; Bouvier et al., 2018). Thus, the primordial environment of the peridotite protocrust in the presence of mantle-derived (e.g., basaltic) melt at shallow depth is favorable for the production of silicaenriched melts provided liquid water is present in sufficient amounts. The mechanism suggested in our study may thus have led to formation of large volumes of the earliest felsic crust.

\section{CONCLUSION}

The proposed mechanism of aqueous fluid-assisted partial melting of peridotite induced by reaction with basaltic melt supports the possibility of felsic crust formation at depths of $\leq 10 \mathrm{~km}$. The shallow depths of generation of felsic magma proposed in this study imply that the formation of silica-rich crust does not require convergent plate tectonics, in agreement with geodynamic simulations of the hotter mantle on early Earth and Mars (Herzberg et al., 2010; Sautter et al., 2016). The most favorable conditions for felsic crust formation are high-temperature interactions between serpentinized peridotite and basaltic melts at $0.2 \mathrm{GPa}$ and low basalt-to-serpentinite mass ratio $(\leq 1)$. Such conditions may have occurred in various geologic settings that do not require modern plate tectonics. Such conditions are highly probable at spreading centers, hot spots and Hadean heat-pipe volcanoes or proto-rifts. A felsic crust may also have been formed in a more transient way during intensive impact-induced melting of the ultramafic-mafic protocrust in the presence of a liquid water ocean on early Earth and Mars. Even though the geodynamic and thermal conditions on both planets have changed, small volumes of felsic crust are still forming by this process at modern spreading centers.

\section{DATA AVAILABILITY STATEMENT}

The datasets presented in this study can be found in online repositories. The names of the repository/repositories and accession number can be found in the article/Supplementary Material, Supplementary Tables S1-S7. 


\section{AUTHOR CONTRIBUTIONS}

$\mathrm{ABo}, \mathrm{AN}, \mathrm{MT}$, and OS developed the conceptual idea of the study; $\mathrm{ABo}$ and NZ, SS prepared and conducted high T-P runs at BGI; $\mathrm{NZ}, \mathrm{OS}, \mathrm{ABy}, \mathrm{AT}, \mathrm{VP}, \mathrm{DV}$ prepared and performed experiments at IEM; NZ, GP, WB, OM conducted thermodynamic modeling; GP, $\mathrm{NZ}$, and AG carried out XAS and SIMS measurements, respectively; KJ, BS, and UW performed LA-ICP-MS analyses. IB performed bulk-rock analyses of serpentinite. ABo, NZ, SG, PP, and $\mathrm{KC}$ performed microanalytical measurements and mapping using EPMA; ABo, AN, GC developed geological applications; all authors contributed to data interpretation and manuscript writing.

\section{FUNDING}

This work is funded by the Institut Carnot ISIFoR "TRACENEO", AST "Planets" in Toulouse (France) and Deutsche Forschungsgemeinschaft (DFG, Germany) to ABo and ATUPS (Université Paul Sabatier, Toulouse, France) for providing a travel grant in 2015-2016 to NZ. This research is fulfilled under the Research Program AAAA-A18-118020590148-3 of the Korzhinskii Institute of Experimental Mineralogy RAS and partially supported by the Russian Scientific Foundation (project 18-17-00206 to OS) and (grant 19-17-00200 to ABy). This work was supported by the French National Research Agency (project RadicalS ANR-16-CE31-0017 to GP and AG) and by the Institut

\section{REFERENCES}

Albarède, F., and Blichert-Toft, J. (2007). The split fate of the early earth, Mars, venus, and moon. C.R. Geosci. 339, 917-927. doi:10.1016/j.crte.2007.09.006

Amri, I., Benoit, M., and Ceuleneer, G. (1996). Tectonic setting for the genesis of oceanic plagiogranites: evidence from a paleo-spreading structure in the Oman ophiolite. Earth Planet. Sci. Lett. 139, 177-194. doi:10.1016/0012-821X(95) 00233-3

Amri, I., Ceuleneer, G., Benoit, M., Python, M., Puga, E., and Targuisti, K. (2007). Genesis of granitoid by interaction between mantle peridotites and hydrothermal fluids in oceanic spreading setting in the Oman Ophiolite. Geogaceta 42, 23-26.

Arai, S. (1997). Origin of podiform chromites. J. Asian Earth Sci. 15, 303-310. doi:10.1016/S0743-9547(97)00015-9

Ballhaus, C., Berry, R. F., and Green, D. H. (1991). High pressure experimental calibration of the olivine-orthopyroxene-spinel oxygen geobarometer: implications for the oxidation state of the upper mantle. Contrib. Mineral. Petrol. 107, 27-40. doi:10.1007/BF00310615

Balta, J. B., Beckett, J. R., and Asimow, P. D. (2011). Thermodynamic properties of alloys of gold-74/palladium-26 with variable amounts of iron and the use of AuPd-Fe alloys as containers for experimental petrology. Am. Mineral. 96, 1467-1474. doi:10.2138/am.2011.3637

Bell, E. A., Boehnke, P., Harrison, T. M., and Wielicki, M. M. (2018). Mineral inclusion assemblage and detrital zircon provenance. Chem. Geology 477, 151-160. doi:10.1016/j.chemgeo.2017.12.024

Benoit, M., Ceuleneer, G., and Polve, M. (1999). The remelting of hydrothermally altered peridotite at mid-ocean ridges by intruding mantle diapirs. Nature 402, 514-518.

Bindeman, I. N. (2008). "Oxygen isotopes in mantle and crustal magmas as revealed by single crystal analysis,". Minerals, inclusions, and volcanic processes, Reviews in Mineralogy and Geochemistry. Editors K. Putirka and F. Tepley, 69, 445-478. doi:10.2138/rmg.2008.69.12
Carnot ISIFoR (project OrPet to GP). IB and OM thank RNF Grant (RNF19-17-00241) for support. Funding from the US National Science Foundation to WB supported this work.

\section{ACKNOWLEDGMENTS}

This study is in tribute to E.Y. Borisova, E.V. Bibikova and Y.V. Bychkova for their works on zircon-based geochronology and Precambrian geology. The first author ABo dedicates this work to the memory of her brother, I.Y. Borisov. We thank Editors SW and $\mathrm{M}$. Pistone, and eight anonymous reviewers for comments and suggestions, that helped to improve the manuscript. F. Spera, E. Sizova, J. Reimink, M. Belosevic, D. Baratoux and A.V. Sobolev are thanked for helpful discussions. We acknowledge the European Synchrotron Radiation Facility for providing access to beamtime, and O. Proux and M. Muñoz for help with XANES data acquisition and processing. C. McCammon and H. Keppler are thanked for offering access to the Bavarian Research Institute of Experimental Geochemistry and Geophysics (Germany). The English style and grammar were post-edited by M.S.N. Carpenter.

\section{SUPPLEMENTARY MATERIAL}

The Supplementary Material for this article can be found online at: https://www.frontiersin.org/articles/10.3389/feart.2021.640464/ full\#supplementary-material

Bohrson, W. A., Spera, F. J., Ghiorso, M. S., Brown, G. A., Creamer, J., and Mayfield, A. (2014). Thermodynamic model for energy-constrained open system evolution of crustal magma bodies undergoing simultaneous assimilation, recharge, and crystallization: the magma chamber simulator. J. Petrology 55, 1685-1717. doi:10.1093/petrology/egu036

Bohrson, W. A., Spera, F. J., Heinonen, J. S., Brown, G. A., Scruggs, M. A., Adams, J. V., et al. (2020). Diagnosing open-system magmatic processes using the Magma Chamber Simulator (MCS): part I- major elements and phase equilibria. Contrib. Mineralogy Petrology 175, 104. doi:10.1007/s00410-02001722-Z

Borisov, A. A., and Shapkin, A. I. (1990). New empirical equation rating $\mathrm{Fe}^{3+} / \mathrm{Fe}^{2+}$ in magmas to their composition, oxygen fugacity, and temperature. Geochem. Int. 27, 111-116.

Borisov, A., Behrens, H., and Holtz, F. (2018). Ferric/ferrous ratio in silicate melts: a new model for 1 atm data with special emphasis on the effects of melt composition. Contrib. Mineral. Petrol. 173, 98. doi:10.1007/s00410-0181524-8

Borisova, A. Y., Ceuleneer, G., Kamenetsky, V., Arai, S., Béjina, F., Abily, B., et al. (2012). A new view on the petrogenesis of the Oman ophiolite chromites from microanalyses of chromite-hosted inclusions. J. Petrology 53, 2411-2440. doi:10.1093/petrology/egs054

Borisova, A. Y., Gurenko, A. A., Martel, C., Kouzmanov, K., Cathala, A., Bohrson, W. A., et al. (2016). Oxygen isotope heterogeneity of arc magma recorded in plagioclase from the 2010 Merapi eruption (Central Java, Indonesia). Geochimica et Cosmochimica Acta 190, 13-34. doi:10.1016/j. gca.2016.06.020

Borisova, A. Y., Martel, C., Gouy, S., Pratomo, I., Sumarti, S., Toutain, J-P., et al. (2013). Highly explosive 2010 Merapi eruption: evidence for shallow-level crustal assimilation and hybrid fluid. J. Volcanol. Geotherm. Res. Spec. Vol. Merapi Eruption. 261, 193-208. doi:10.1016/j.jvolgeores.2012.11.002

Borisova, A. Y., Pichavant, M., Beny, J.-M., Rouer, O., and Pronost, J. (2005). Constraints on degassing of dacite magma and regime of the June 15, 1991, 
climactic eruption of Mount Pinatubo (Philippines): new data on melt and crystal inclusions in quartz. J. Volcanol. Geotherm. Res. 145, 35-67. doi:10.1016/ j.jvolgeores.2005.01.004

Borisova, A. Y., Pokrovski, G. S., Pichavant, M., Freydier, R., and Candaudap, F. (2010). Arsenic enrichment in hydrous peraluminous melts: insights from LAICP-MS and in situ X-ray Absorption Spectroscopy. Am. Mineral. 95, 1095-1104. doi:10.2138/am.2010.3424

Borisova, A. Y., Zagrtdenov, N. R., Toplis, M. J., Ceuleneer, G., Safonov, O. G., Pokrovski, G. S., et al. (2020a). Hydrated peridotite - basaltic melt interaction Part II: fast assimilation of serpentinized mantle by basaltic magma. Front. Earth Sci 8, 84. doi:10.3389/feart.2020.00084

Borisova, A. Y., Jochum, K. P., and Gouy, S. (2020b). Mineralogical and geochemical features of the Allan Hills tephra, South Victoria Land: implications for mid-Pleistocene volcanic activity in Antarctica. Polar Sci. 23. doi:10.1016/j.polar.2020.100505

Borisova, A. Y., Bindeman, I. N., Toplis, M. J., Zagrtdenov, N. R., Guignard, J., Safonov, O. G., et al. (2020c). Zircon survival in shallow asthenosphere and deep lithosphere. Am. Mineral. 105, 1662-1671. doi:10.3389/feart.2020.00084

Bouvier, L. C., Costa, M. M., Connelly, J. N., Jensen, N. K., Wielandt, D., Storey, M., et al. (2018). Evidence for extremely rapid magma ocean crystallization and crust formation on Mars. Nature 558, 586-589. doi:10.1038/s41586-018-0222-z

Brimhall, G. H., and Crerar, D. A. (1987). Ore fluids: magmatic to supergene. Rev. Mineral. 17, 235-321. doi:10.1515/9781501508950-010

Bromiley, G., Hilaret, N., and McCammon, C. (2004). Solubility of hydrogen and ferric iron in rutile and $\mathrm{TiO}_{2}$ (II): implications for phase assemblages during ultrahigh-pressure metamorphism and for the stability of silica polymorphs in the lower mantle. Geophys. Res. Lett. 31, L04610. doi:10.1029/2004GL019430

Burnham, A. D., and Berry, A. J. (2017). Formation of the Hadean granites by melting of igneous crust. Nat. Geosci. 10, 457-462. doi:10.1038/ngeo2942

Cannat, M. (1993). Emplacement of mantle rocks in the sea-floor at mid-ocean ridges. J. Geophys. Research-Solid Earth 98 (B3), 4163-4172. doi:10.1029/92JB02221

Capitanio, F. A., Nebel, O., and Cawood, P. A. (2020). Thermochemical lithosphere differentiation and the origin of cratonic mantle. Nature 588, 89-94. doi:10. 1038/s41586-020-2976-3

Carignan, J., Hild, P., Mevelle, G., Morel, J., Yeghicheyan, D., Dr-N, Ub-N, et al. (2001). Routine analyses of trace elements in geological samples using flow injection and low pressure on-line liquid chromatography coupled to ICP-MS: a study of geochemical reference materials BR. Geostand. Geoanal. Res. 25, 187-198. doi:10.1111/j.1751-908X.2001.tb00595.x

Cavosie, A. J., Valley, J. W., Wilde, S. A., and F., E. I. M. (2006). Correlated microanalysis of zircon: trace element, $\delta^{18} \mathrm{O}$, and $\mathrm{U}-\mathrm{Th}-\mathrm{Pb}$ isotopic constraints on the igneous origin of complex $>3900 \mathrm{Ma}$ detrital grains. Geochim. Cosmochim. Acta 70, 5601-5616. doi:10.1016/j.gca.2006.08.011

Coleman, R. G., and Peterman, Z. E. (1975). Oceanic plagiogranites. J. Geophys. Res. 80, 1099-1108. doi:10.1029/JB080i008p01099

Deschamps, F., Guillot, S., Godard, M., and Chauvel, C. (2010). In situ characterization of serpentinites from forearc mantle wedges: timing of serpentinization and behavior of fluid-mobile elements in subduction zones. Chem. Geol. 269, 262-277. doi:10.1016/j.chemgeo.2009.10.002

Deubener, J., Müller, R., Behrens, H., and Heide, G. (2003). Water and glass transition temperature of silicate melts. J. Non-Cristalline Sol. 330, 268-273. doi:10.1016/S0022-3093(03)00472-1

Diakonov, I. I., Pokrovski, G. S., Schott, J., Castet, S., and Gout, R. (1996). An experimental and computational study of $\mathrm{Na}-\mathrm{Al}$ complexing in crustal fluids. Geochim. Cosmochim. Acta 60, 197-211. doi:10.1016/0016-7037(95)00403-3

Dick, H. J. B. (1977). "Evidence of partial melting in the josephine peridotite,". Magma genesis: proceedings of the American geophysical union chapman conference on partial melting in the earth's upper mantle: state of Oregon department of geology and mineral industries. Editor H. J. B. Dick, 59-62. doi:10.2475/ajs.277.7.801

Ehlmann, B. L., Mustard, J. F., and Murchie, S. L. (2010). Geologic setting of serpentine deposits on Mars. Geophys. Res. Lett. 37, L06201. doi:10.1029/ 2010GL042596

Elkins-Tanton, L. T. (2012). Magma ocean in the inner Solar system. Ann. Rev. Earth Planet. Sci. 40, 113-139. doi:10.1146/annurev-earth-042711-105503

Fisk, M. R. (1986). Basalt magma interaction with harzburgite and the formation of high-magnesium andesites. Geophys. Res. Lett. 13, 467-470. doi:10.1029/ GL013i005p00467
Ghiorso, M. S., and Sack, R. O. (1995). Chemical mass transfer in magmatic processes IV. A revised and internally consistent thermodynamic model for the interpolation and extrapolation of liquid-solid equilibria in magmatic systems at elevated temperatures and pressures. Contrib. Mineral. Petrol. 119, 197-212. doi:10.1007/BF00307281

Govindaraju, K. (1994). Compilation of working values and sample description for 383 geostandards. Geostand. Newslett. 18, 1-158. doi:10.1046/j.1365-2494.1998. 53202081.x-i1

Green, D. H. (1973). Experimental melting studies on a model upper mantle composition at high pressure under water saturated and water undersaturated conditions. Earth Planet. Sci. Lett. 19, 37-53. doi:10.1016/0012-821X(73)90176-3

Guillot, S., and Hattori, K. (2013). Serpentinites: essential roles in geodynamics, arc volcanism, sustainable development, and the origin of life. Elements 9, 95-98. doi:10.2113/gselements.9.2.95

Gurenko, A. A., Kamenetsky, V. S., and Kerr, A. C. (2016). Oxygen isotopes and volatile contents of the Gorgona komatiites, Colombia: a confirmation of the deep mantle origin of $\mathrm{H}_{2} \mathrm{O}$. Earth Planet. Sci. Lett. 454, 154-165. doi:10.1016/j. epsl.2016.08.035

Harrison, T. M. (2009). The Hadean crust: evidence from > 4 Ga zircons. Annu. Rev. Earth Planet. Sci. 37, 479-505. doi:10.1146/annurev.earth.031208.100151

Heinonen, J. S., Bohrson, W. A., Spera, F. J., Brown, G. A., Scruggs, M. A., and Adams, J. V. (2020). Diagnosing open-system magmatic processes using the Magma Chamber Simulator (MCS): part II- trace elements and isotopes. Contrib. Mineralogy Petrology 175, 105. doi:10.1007/s00410-020-01718-9

Helgeson, H. C., Kirkham, D. H., and Flowers, G. C. (1981). Theoretical prediction of thermodynamic behavior of aqueous electrolytes at high temperatures and pressures. IV. Calculation of activity coefficients, osmotic coefficients, and apparent molal and standard and relative partial molal properties to $5 \mathrm{~kb}$ and $600{ }^{\circ}$ C. Am. J. Sci. 281, 1249-1516. doi:10.2475/ajs.281.10.1249

Herzberg, C., Condie, K., and Koregana, J. (2010). Thermal history of the Earth and its petrological expression. Earth Planet. Sci. Lett. 292, 79-88. doi:10.1016/j.epsl. 2010.01.022

Hirschmann, M. M., Baker, M. B., and Stolper, E. M. (1998). The effect of alkalis on the silica content of mantle-derived melts. Geochim. Cosmochim. Acta 62, 883-902. doi:10.1016/S0016-7037(98)00028-3

Holland, T. J. B., and Powell, R. (2011). An improved and extended internally consistent thermodynamic dataset for phases of petrological interest, involving a new equation of state for solids. J. Metamorphic Geol. 29, 333-383. doi:10. $1111 /$ j.1525-1314.2010.00923.x

Jochum, K. P., Nohl, U., Herwig, K., Lammel, E., Stoll, B., and Hofmann, A. W. (2005). GeoReM: A new geochemical database for reference materials and isotopic standards. Geostandards Geoanalytical Res. 29, 333-338. doi:10.1111/j. 1751-908X.2005.tb00904.x

Jochum, K. P., Stoll, B., Herwig, K., Willbold, M., Hofmann, A. W., Amini, M., et al. (2006). MPI-DING reference glasses for in situ microanalysis: new reference values for element concentrations and isotope ratios. Geochem. Geophys. Geosystems 7, Q02008. doi:10.1029/2005GC001060

Jochum, K. P., Stoll, B., Herwig, K., and Willbold, M. (2007). Validation of LA-ICPMS trace element analysis of geological glasses using a new solid-state $193 \mathrm{~nm}$ Nd:YAG laser and matrix-matched calibration. J. Anal. Spectrom. 22, 112-121. doi:10.1039/B609547J

Jochum, K. P., Stoll, B., Weis, U., Jacob, D. E., Mertz-Kraus, R., and Andreae, M. O. (2014). Non-matrix-matched calibration for the multi-element analysis of geological and environmental samples using $200 \mathrm{~nm}$ femtosecond LA-ICPMS: a comparison with nanosecond lasers. Geostandards Geoanalytical Res. 38 , 265-292. doi:10.1111/j.1751-908X.2014.12028.x

Johnson, J. W., Oelkers, E. H., and Helgeson, H. C. (1992). SUPCRT92: A software package for calculating the standard molal thermodynamic properties of minerals, gases, aqueous species, and reactions from 1 to 5000 bar and 0 to $1000{ }^{\circ} \mathrm{C}$. Comput. Geosci. 18, 899-947. doi:10.1016/ 0098-3004(92)90029-Q

Kelemen, P. B., Joyce, D. B., Webster, J. D., and Holloway, J. R. (1990). Reaction between ultramafic rock and fractionating basaltic magma II. Experimental investigation of reaction between olivine tholeiite and harzburgite at 1150$1050^{\circ} \mathrm{C}$ and 5kb. J. Petrology 31, 99-134. doi:10.1093/petrology/31.1.99

Kelemen, P. B., Shimizu, N., and Salters, V. J. M. (1995). Extraction of mid-oceanridge basalt from the upwelling mantle by focused flow of melt in dunite channels. Nature 375, 747-753. doi:10.1038/375747a0 
Koepke, J., Feig, S., Snow, J., and Freise, M. (2004). Petrogenesis of oceanic plagiogranites by partial melting of gabbros: an experimental study. Contrib. Mineral. Petrol. 146, 414-432. doi:10.1007/s00410-003-0511-9

Kouzmanov, K., and Pokrovski, G. S. (2012). "Hydrothermal controls on metal distribution in $\mathrm{Cu}(-\mathrm{Au}-\mathrm{Mo})$ porphyry systems,". Geology and genesis of geology and genesis of major copper deposits and districts of the world: a tribute to richard H. Sillitoe. Editors J. W. Hedenquist, M. Harris, and F. Camus (Littleton, CO: Society of Economic Geologists Special Publication), 16, 573-618. doi:10. 5382/SP.16.22

Kushiro, I (1968). Compositions of magmas formed by partial zone melting of the Earth's upper mantle. J. Geophys. Res. 73, 619-634. doi:10.1029/JB073i002p00619

Le Maitre, R. W. (2002). Igneous rocks. A classification and glossary of terms. Recommendations of the international union of geological sciences subcommission on the systematics of igneous rocks. 2nd ed. Cambridge, New York, Melbourne: Cambridge University Press, 236. doi:10.1017/ CBO9780511535581

Lundstrom, C. C. (2000). Rapid diffusive infiltration of sodium into partially molten peridotite. Nature 403, 527-530. doi:10.1038/35000546

Lyubetskaya, T., and Korenaga, J. (2007). Chemical composition of Earth's primitive mantle and its variance: 1 . Method and results. J. Geophys. Res. 112, B03211. doi:10.1029/2005JB004223

Marchi, S., Bottke, W. F., Elkins-Tanton, L. T., Bierhaus, M., Wuennemann, K., Morbidelli, A., et al. (2014). Widespread mixing and burial of Earth's Hadean crust by asteroid impacts. Nature 511, 578-582. doi:10.1038/nature13539

Martel, C., Dingwell, D. B., Spieler, O., Pichavant, M., and Wilke, M. (2000). Fragmentation of foamed silicic melts: an experimental study. Earth Planet. Sci. Lett. 178, 47-58. doi:10.1016/S0012-821X(00)00062-5

Matjuschkin, V., Brooker, R. A., Tattitch, B., Blundy, J. D., and Stamper, C. C. (2015). Control and monitoring of oxygen fugacity in piston cylinder experiments. Contrib. Mineral. Petrol. 171, 66. doi:10.1007/s00410-016-1274-4

Moore, W. B., and Webb, A. A. (2013). Heat-pipe earth. Nature 501, 501-505. doi:10.1038/nature12473

Morgan, Z., and Liang, Y. (2003). An experimental and numerical study of the kinetics of harzburgite reactive dissolution with application to dunite formation. Earth Planet. Sci. Lett. 214, 59-74. doi:10.1016/S0012-821X(03) 00375-3

Moyen, J.-F., and Martin, H. (2012). Forty years of TTG research. Lithos 148, 312-336. doi:10.1016/j.lithos.2012.06.010

Muñoz, M., Vidal, O., Marcaillou, C., Pascarelli, S., Mathon, O., and Farges, F. (2013). Iron oxidation state in phyllosilicate single crystals using Fe-K pre-edge and XANES spectroscopy: effects of the linear polarization of the synchrotron X-ray beam. Amer. Miner. 98, 1187-1197. doi:10.2138/am.2013.4289

Müntener, O. (2010). Serpentine and serpentinization: a link between planet formation and life. Geology 38, 959-960. doi:10.1130/focus102010.1

Nédélec, A., Monnereau, M., and Toplis, M. (2017). The Hadean-Archaean transition at $4 \mathrm{Ga}$ : from magma trapping in the mantle to volcanic resurfacing of the Earth. Terra Nova 29, 218-223. doi:10.1111/ter.12266

Nicholls, I. A., Ringwood, A. E., O'Neil, J., and Carlson, R. W. (1973). Effect of water on olivine stability in tholeiites and the production of silica-saturated magmas in the island-arc environment. J. Geology Science 81, 285-300. doi:10. $1086 / 627871$

Oelkers, E. H., Benezeth, P., and Pokrovski, G. S. (2009). "Thermodynamic databases for water-rock interaction,". Thermodynamics and kinetics of water-rock interactions. Editors E. H. Oelkers and J. Schott (Mineralogical Society of America and Geochemical Society. Rev. Miner. Geochem.), 70, 1-46. doi:10.2138/rmg.2009.70.1

Oliphant, T. E. (2006). Guide to NumPy. USA: Massachusetts Institute of Technology, 261.

O'Hara, M. J., and Mathews, R. E. (1981). Geochemical evolution in an advancing, periodically replenished, periodically tapped, continuously fractionated magma chamber. J. Geol. Soc. 138, 237-277. doi:10.1144/gsggs.138.3.0237

O'Neil, J., and Carlson, R. W. (2017). Building Archean cratons from Hadean mafic crust. Science 355, 1199-1202.

Pietranik, A., Storey, C., Koepke, J., Lasalle, S., and EIMF (2017). Zircon record of fractionation, hydrous partial melting and thermal gradients at different depths in oceanic crust (ODP Site 735B, South-West Indian Ocean). Contrib. Mineral. Petrol. 172, 10. doi:10.1007/s00410-016-1324-y
Pokrovski, G. S., Borisova, A. Y., and Bychkov, A. Y. (2013). "Speciation and transport of metals and metalloids in geological vapors," in Book chapter 6 in: thermodynamics of geothermal fluids. Reviews in Mineralogy \& Geochemistry. Editors A. Stefánsson, T. Driesner, and P. Bénézeth, 76, 165-218. doi:10.2138/ rmg.2013.76.6

Pokrovski, G. S., Schott, J., Hazemann, J.-L., Farges, F., and Pokrovsky, O. S. (2002). An X-ray Absorption Fine Structure and Nuclear Magnetic Resonance spectroscopy study of gallium-silica complexes in aqueous solution. Geochimica et Cosmochimica Acta 66, 4203-4322. doi:10.1016/S00167037(02)00973-0

Pouchou, J. L., and Pichoir, F. (1991). "Qualitative analysis of homogeneous or stratified microvolumes applying the model "PAP"," in Electron probe quantitation. Editors K. F. J. Heinrich and D. E. (NewburyNew York: Plenum Press). doi:10.1007/978-1-4899-2617-3_4

Proux, O., Biquard, X., Lahera, E., Menthonnex, J-J., Prat, A., Ulrich, O., et al. (2005). FAME: a new beamline for X-ray absorption investigations of very diluted systems of environmental, material and biological interests. Phys. Scripta T115, 970-973. doi:10.1238/Physica.Topical.115a00970

Reimink, J. R., Chacko, T., Stern, R. A., and Heaman, L. M. (2014). Earth's earliest evolved crust generated in an Iceland-like setting. Nature 7, 529-533. doi:10. 1038/NGEO2170

Reimink, J. R., Chacko, T., Stern, R. A., and Heaman, L. M. (2016). The birth of a cratonic nucleus: lithogeochemical evolution of the 4.02-2.94 Ga Acasta Gneiss complex. Precambrian Res. 281, 453-472. doi:10.1016/j.precamres. 2016.06.007

Robie, R. A., and Hemingway, B. S. (1995). Thermodynamic properties of minerals and related substances at $298.15 \mathrm{~K}$ and 1 bar $\left(10^{5}\right.$ Pascals $)$ pressure and at higher temperatures. U.S. Geol. Surv. Bull. 2131. doi:10.3133/b213

Rospabé, M., Ceuleneer, G., Granier, N., Arai, S., and Borisova, A. Y. (2019). Multiscale development of a stratiform chromite ore body at the base of the dunitic mantle-crust transition zone (Maqsad diapir, Oman ophiolite): the role of repeated melt and fluid influxes. Lithos 350-351, 10523536. doi:10.1016/j.lithos. 2019.105235

Rudnick, R. L., and Gao, S. (2003). Composition of the continental crust, Treatise Geochem., 3, 1-64. doi:10.1029/95RG01302

Rudnick, R. L. (1995). Making continental crust. Nature 378, 571-578. doi:10.1038/ 378571a0

Safonov, O. G., Kosova, S. A., and Van Reenen, D. D. (2014). Interaction of biotiteamphibole gneiss with $\mathrm{H}_{2} \mathrm{O}-\mathrm{CO}_{2}-(\mathrm{K}, \mathrm{Na}) \mathrm{Cl}$ fluids at $550 \mathrm{MPa}$ and 750 and $800^{\circ} \mathrm{C}$ : experimental study and applications to dehydration and partial melting in the middle crust. J. Petrology 55, 2419-2456. doi:10.1093/petrology/egu062

Salvi, S., Pokrovski, G. S., and Schott, J. (1998). Experimental investigation of aluminum-silica aqueous complexing at $300^{\circ} \mathrm{C}$. Chem. Geology. 151, 51-67. doi:10.1016/S0009-2541(98)00070-9

Sautter, V., Toplis, M. J., Beck, P., Mangold, N., Wiens, R., Pinet, P., et al. (2016). Magmatic complexity on early Mars as seen through a combination of orbital, in-situ and meteorite data. Lithos 254-255, 36-52. doi:10.1016/j.lithos.2016. 02.023

Sautter, V., Toplis, M. J., Wiens, R. C., and Cousin, A. (2015). In situ evidence for continental crust on early Mars. Nat. Geosci. 3, 605-609. 10.1038/ngeo2474

Savin, S. M., and Lee, M. (1988). "Isotopic studies of phyllosilicate," in Hydrous phyllosilicate (exclusive of micas), Rev Mineral 19. Editor S. W. Bailey (Washington, DC: Mineral Soc Am.), 189-223.

Shaw, C. S. J., and Dingwell, D. B. (2008). Experimental peridotite-melt reaction at one atmosphere: a textural and chemical study. Contrib. Mineral. Petrol. 155, 199-214. doi:10.1007/s00410-007-0237-1

Shaw, C. S. J. (1999). Dissolution of orthopyroxene in basanitic magma between 0.4 and $2 \mathrm{GPa}$ : further implications for the origin of Si-rich alkaline glass inclusions in mantle xenoliths. Contrib. Mineral. Petrol. 135, 114-132. doi:10.1007/ s004100050501

Shaw, C. S. J., Thibault, Y., Edgar, A. D., and Lloyd, F. E. (1998). Mechanisms of orthopyroxene dissolution in silica-undersaturated melts at 1 atmosphere and implications for the origin of silica-rich glass in mantle xenoliths. Contrib. Mineral. Petrol. 132, 354-370. doi:10.1007/s004100050429

Shervais, J. W. (2008). "Tonalites, trondhjemites, and diorites of the Elder Creek ophiolite, California: low-pressure slab melting and reaction with the mantle wedge,". Ophiolites, arcs, and batholiths: a tribute to cliff hopson. Editors 
J. E. Wright and J. W. Shervais (University of Virginia), 438, 113-132. doi:10. $1130 / 2008.2438(03)$

Shock, E. L., Sassani, D. C., Willis, M., and Sverjensky, D. A. (1997). Inorganic species in geologic fluids: correlations among standard molal thermodynamic properties of aqueous ions and hydroxide complexes. Geochim. Cosmochim. Acta. 61, 907-950. doi:10.1016/s0016-7037(96)00339-0

Shvarov, Y. V. (2015). A suite of programs, OptimA, OptimB, OptimC, and Optims compatible with the Unitherm database, for deriving the thermodynamic properties of aqueous species from solubility, potentiometry and spectroscopy measurements. Appl. Geochem. 55, 17-27. doi:10.1016/j. apgeochem.2014.11.021

Shvarov, Y. V. (2008). HCh: new potentialities for the thermodynamic simulation of geochemical systems offered by Windows. Geochem. Intern. 46, 834-839. doi:10.1134/S0016702908080089

Sun, S.-S., and McDonough, W. M. (1989). "Chemical and isotope systematics of oceanic basalts: implications for mantle compositions and processes,". Magmatism in the ocean basins. Editors A. D. Saunders and M. J. Norry (London: Geological Society of London), 42, 313-345. doi:10.1144/GSL.SP. 1989.042.01.19

Sushchevskaya, N. M., Korago, E. A., Belyatsky, B. V., and Sirotkin, A. N. (2000). Magmatism of mona and Knipovich ridges from spreading zones of polar atlantic ocean. Russ. J. Geosciences. 2, 243-267. doi:10.1134/\$0016702909100024

Sverjensky, D. A., Shock, E. L., and Helgeson, H. C. (1997). Prediction of the thermodynamic properties of aqueous metal complexes to 1000 degrees $C$ and 5 kb. Geochim. Cosmochim. Acta. 61, 1359-1412. doi:10.1016/s0016-7037(97) 00009-4

Sverjensky, D. A., Harrison, B., and Azzolini, D. (2014). Water in the deep Earth: the dielectric constant and the solubilities of quartz and corundum to $60 \mathrm{~kb}$ and $1200{ }^{\circ} \mathrm{C}$. Geochim. Cosmochim. Acta. 129, 125-145. doi:10.1016/j.gca.2013.12.019

Tagirov, B., and Schott, J. (2001). Aluminum speciation in crustal fluids revisited. Geochim. Cosmochim. Acta. 65, 3965-3992. doi:10.1016/S0016-7037(01) 00705-0

Tanger, J. C., and Helgeson, H. C. (1988). Calculation of the thermodynamic and transport properties of aqueous species at high pressures and temperatures: revised equation of state for the standard partial molal properties of ions and electrolytes. Am. J. Sci. 288, 19-98. doi:10.2475/ajs.288.1.19

Toplis, M. J. (2005). The thermodynamics of iron and magnesium partitioning between olivine and liquid: criteria for assessing and predicting equilibrium in natural and experimental systems Contrib. Mineral. Petrol. 149, 22-39. doi:10. 1007/s00410-004-0629-4

Trail, D., Watson, E. B., and Tailby, N. D. (2011). The oxidation state of Hadean magmas and implications for early Earth's atmosphere. Nature 480, 79-82. doi:10.1038/nature10655

Turek, A., Riddle, C., Cozens, B. J., Tetley, N. W., Udry, A., Gazel, E., et al. (1976). Determination of chemical water in rock analysis by Karl Fischer titration. Chem. Geol. J. Geophys. Res. Planets 17, 261-267. doi:10.1029/2018JE005602

Udry, A., Gazel, E., and McSween, H. Y. (2018). Formation of evolved rocks at Gale crater by crystal fractionation and implications for Mars crustal composition. J. Geophys. Res. Plan. 123, 1525-1540. doi:10.1029/2018JE005602

Ulmer, P. (2001). Partial melting in the mantle wedge - the role of $\mathrm{H}_{2} \mathrm{O}$ in the genesis of mantle-derived 'arc-related' magmas. Phys. Earth Planet. Inter. 127, 215-232. doi:10.1016/S0031-9201(01)00229-1
Valley, J. W., Peck, W. H., King, E. M., and Wilde, S. A. (2002). A cool early Earth. Geology 30, 351-354. doi:10.1130/0091-7613(2002)030<0351:ACEE>2.0.CO;2

Van den Bleeken, G., Müntener, O., and Ulmer, P. (2011). Melt variability in percolated peridotite: an experimental study applied to reactive migration of tholeiitic basalt in the upper mantle. Contrib. Mineral. Petrol. 161, 921-945. doi:10.1007/s00410-010-0572-5

Van den Bleeken, G., Müntener, O., and Ulmer, P. (2010). Reaction processes between tholeiitic melt and residual peridotite in the uppermost mantle: an experimental study at $0.8 \mathrm{GPa}$ J. Petrol. 51, 153-183. doi:10.1093/petrology/egp066

Veksler, I. V., and Hou, T. (2020). Experimental study on the effects of $\mathrm{H}_{2} \mathrm{O}$ upon crystallization in the Lower and Critical Zones of the Bushveld Complex with an emphasis on chromite formation. Contrib. Mineralogy Petrology. 175, 85. doi:10.1007/s00410-020-01733-w

Wedepohl, K. H. (1995). The composition of the continental crust. Geochim. Cosmochim. Acta 59, 1217-1232. doi:10.1016/0016-7037(95)00038-2

Westrich, H. R. (1987). Determination of water in volcanic glasses by Karl-Fischer titration. Chem. Geol. 63, 335-340. doi:10.1016/0009-2541(87)90170-7

Whitehouse, M. J., Nemchin, A. A., and Pidgeon, R. T. (2017). What can Hadean detrital zircon really tell us? A critical evaluation of their geochronology with implications for the interpretation of oxygen and hafnium isotopes. Gondwana Res. 51, 78-91. doi:10.1016/j.gr.2017.07.007

Wilke, M., Farges, F., Petit, P., Brown, G., Jr., and Martin, F. (2001). Oxidation state and coordination of Fe in minerals: an Fe K-XANES spectroscopic study. Am. Mineral. 86, 714-730. doi:10.2138/am-2001-5-612

Wilke, M., Partzsch, G., Bernhardt, R., and Lattard, D. (2005). Determination of the iron oxidation state in basaltic glasses using XANES at the K-edge. Chem. Geol. 220, 143-161. doi:10.1016/j.chemgeo.2005.03.004

Xu, Y., Liu, C.-Z., Chen, Y., Guo, S., Wang, J.-G., and Sein, K. (2017). Petrogenesis and tectonic implications of gabbro and plagiogranite intrusions in mantle peridotite of the Myitkyina ophiolite, Myanmar. Lithos 284-285, 180-193. doi:10.1016/j.lithos.2017.04.014

Zagrtdenov, N. R., Ceuleneer, G., Rospabé, M., Borisova, A. Y., Toplis, M. J., Benoit, M., et al. (2018). Anatomy of a chromite dyke in the mantle - crust transition zone of the Oman ophiolite. Lithos 312, 343-357. doi:10.1016/j. lithos.2018.05.012

Zimmer, K., Zhang, Y., Lu, P., Chen, Y., Zhang, G., Dalkilic, M., et al. (2016). A revised and extended thermodynamic dataset software package of SUPCRT92. Comput. Geosciences 90, 97-111. doi:10.1016/j.cageo.2016.02.013

Conflict of Interest: The authors declare that the research was conducted in the absence of any commercial or financial relationships that could be construed as a potential conflict of interest.

Copyright (C) 2021 Borisova, Zagrtdenov, Toplis, Bohrson, Nédélec, Safonov, Pokrovski, Ceuleneer, Bindeman, Melnik, Jochum, Stoll, Weis, Bychkov, Gurenko, Shcheka, Terehin, Polukeev, Varlamov, Chariteiro, Gouy and de Parseval. This is an open-access article distributed under the terms of the Creative Commons Attribution License (CC BY). The use, distribution or reproduction in other forums is permitted, provided the original author(s) and the copyright owner(s) are credited and that the original publication in this journal is cited, in accordance with accepted academic practice. No use, distribution or reproduction is permitted which does not comply with these terms. 